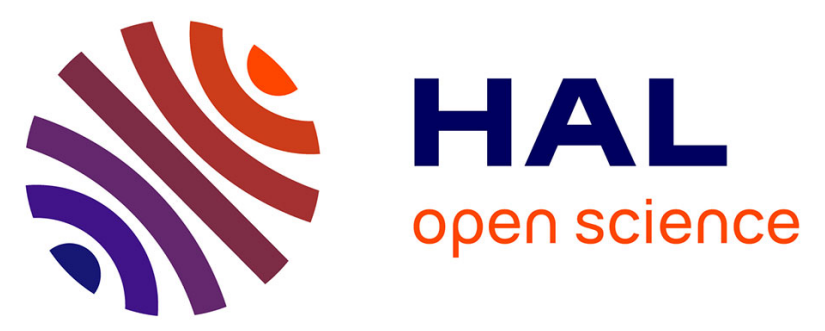

\title{
Variable late Neogene exhumation of the central European Alps: Low-temperature thermochronology from the Aar Massif, Switzerland, and the Lepontine Dome, Italy
}

Antoine Vernon, Peter A. van Der Beek, H. Sinclair, C. Persano, J. Foeken, F.M Stuart

\section{To cite this version:}

Antoine Vernon, Peter A. van Der Beek, H. Sinclair, C. Persano, J. Foeken, et al.. Variable late Neogene exhumation of the central European Alps: Low-temperature thermochronology from the Aar Massif, Switzerland, and the Lepontine Dome, Italy. Tectonics, 2009, 28, pp.TC5004. 10.1029/2008TC002387 . insu-00411867

\section{HAL Id: insu-00411867 https://hal-insu.archives-ouvertes.fr/insu-00411867}

Submitted on 4 Mar 2021

HAL is a multi-disciplinary open access archive for the deposit and dissemination of scientific research documents, whether they are published or not. The documents may come from teaching and research institutions in France or abroad, or from public or private research centers.
L'archive ouverte pluridisciplinaire HAL, est destinée au dépôt et à la diffusion de documents scientifiques de niveau recherche, publiés ou non, émanant des établissements d'enseignement et de recherche français ou étrangers, des laboratoires publics ou privés. 


\title{
Variable late Neogene exhumation of the central European Alps: Low-temperature thermochronology from the Aar Massif, Switzerland, and the Lepontine Dome, Italy
}

\author{
Antoine J. Vernon, ${ }^{1,2,3}$ Peter A. van der Beek, ${ }^{1}$ Hugh D. Sinclair, ${ }^{2}$ Cristina Persano, ${ }^{4}$ \\ Jurgen Foeken, ${ }^{5}$ and Finlay M. Stuart ${ }^{5}$ \\ Received 2 September 2008; revised 5 April 2009; accepted 2 July 2009; published 16 September 2009.
}

[1] Several recent studies proposed an important increase in exhumation rate in the western European Alps since circa 5-4 Ma. In order to assess potential spatial differences in exhumation histories, we present new apatite fission track (AFT) and apatite (U-Th)/He (AHe) ages from the central Aar Massif (Guttannen area, Switzerland) and the western Lepontine Dome (Formazza area, Italy). Internal U/Th zoning in apatites explains alpha-ejection-corrected $\mathrm{AHe}$ ages that are older than the corresponding AFT ages in this study. A qualitative interpretation of AFT and AHe ageelevation relationships suggests a two-phase (9-7 and 5-3 Ma) exhumation scenario affecting the central Alps, with a stronger expression of the Pliocene signal in the Formazza area. However, a quantitative evaluation of exhumation scenarios using the 3-D heat equation solver Pecube highlights the existence of several other likely scenarios, casting doubt on the validity of a qualitative interpretation of the age-elevation relationships. In Formazza, scenarios suggested by quantitative modeling include continuous denudation at a rate of $\sim 750 \mathrm{~m} / \mathrm{Ma}$ and a one-step exhumation rate change from 300 to $1000 \mathrm{~m} / \mathrm{Ma}$ at $5 \mathrm{Ma}$. In Guttannen, they include continuous denudation at a rate of $\sim 400 \mathrm{~m} / \mathrm{Ma}$ with valley deepening and two periods of higher exhumation rate (increasing from 300 to $700 \mathrm{~m} / \mathrm{Ma}$ repeatedly at $9-7$ and at 5-3 Ma). Contingent upon further flexural isostatic modeling, the magnitude of exhumation recorded in the axial region of the Alps since circa $5 \mathrm{Ma}$ does not appear sufficient to solely explain the denudation recorded in the North Alpine Foreland Basin. Citation: Vernon, A. J., P. A. van der Beek, H. D. Sinclair, C. Persano, J. Foeken, and F. M. Stuart (2009),

\footnotetext{
${ }^{1}$ Laboratoire de Géodynamique des Chaînes Alpines, Université Joseph Fourier, Grenoble, France.

${ }^{2}$ School of Geosciences, University of Edinburgh, Edinburgh, UK.

${ }^{3}$ Now at Department of Geosciences, University of Arizona, Tucson, Arizona, USA.

${ }^{4}$ Department of Geographical and Earth Sciences, University of Glasgow, Glasgow, UK

${ }^{5}$ Isotope Geosciences Unit, Scottish Universities Environmental Research Centre, East Kilbride, UK.
}

Copyright 2009 by the American Geophysical Union. 0278-7407/09/2008TC002387
Variable late Neogene exhumation of the central European Alps: Low-temperature thermochronology from the Aar Massif, Switzerland, and the Lepontine Dome, Italy, Tectonics, 28, TC5004, doi:10.1029/2008TC002387.

\section{Introduction}

[2] Sediment volumes from around the globe record an increase in sediment accumulation rates during the Pliocene [Davies et al., 1977; Zhang et al., 2001; Molnar, 2004]. This increase is also recorded by sediments shed from the European Alps [Kuhlemann, 2000; Willett et al., 2006]. Together with the documented exhumation of the North Alpine Foreland Basin since circa 5-4 Ma, this observation led Cederbom et al. [2004] to propose that the bulk of the Alps experienced accelerated exhumation and isostatic rebound since Early Pliocene times. Evidence for significant tectonic deformation during this period is not compelling, and therefore climate change has been proposed as the driving mechanism for increased erosion rates [Cederbom et al., 2004]. Consequently, the axial Alpine crystalline massifs should have been subjected to accelerated denudation during the Pliocene. The uniquely dense apatite fission track (AFT) record in the western European Alps has been used to derive exhumation rates for the period spanning from 13.5 to $2.5 \mathrm{Ma}$ [Vernon et al., 2008]. In addition to supporting the hypothesis of overall accelerating denudation around $5 \mathrm{Ma}$, this analysis reveals a spatial diachroneity in exhumation on $50-100 \mathrm{~km}$ wavelengths, with accelerations starting between $6.5 \mathrm{Ma}$ and $2.5 \mathrm{Ma}$ or later [Vernon et al., 2008]. Refining the description of this heterogeneity in exhumation history by further and more detailed thermochronometric analyses may be key to distinguish between a model of variable, but diffuse exhumation since $5 \mathrm{Ma}$, in response to the erosional decay of the orogen, versus a model of localized exhumation associated with differential rock uplift across active faults during the late stages of plate convergence.

[3] Here, we test for regional variations in late Neogene exhumation along a north-south transect in the central Alps (Figures 1 and 2). We use apatite fission track (AFT) and apatite $(\mathrm{U}-\mathrm{Th}) / \mathrm{He}(\mathrm{AHe})$ ages along elevation profiles from the Aar Massif and the Lepontine Dome, completed by fifteen samples along the transect (Table 1). The transect projects into the mountain belt from the well data of the North Alpine Foreland Basin studied by Cederbom et al. [2004]. After describing the dating methods and results, we 

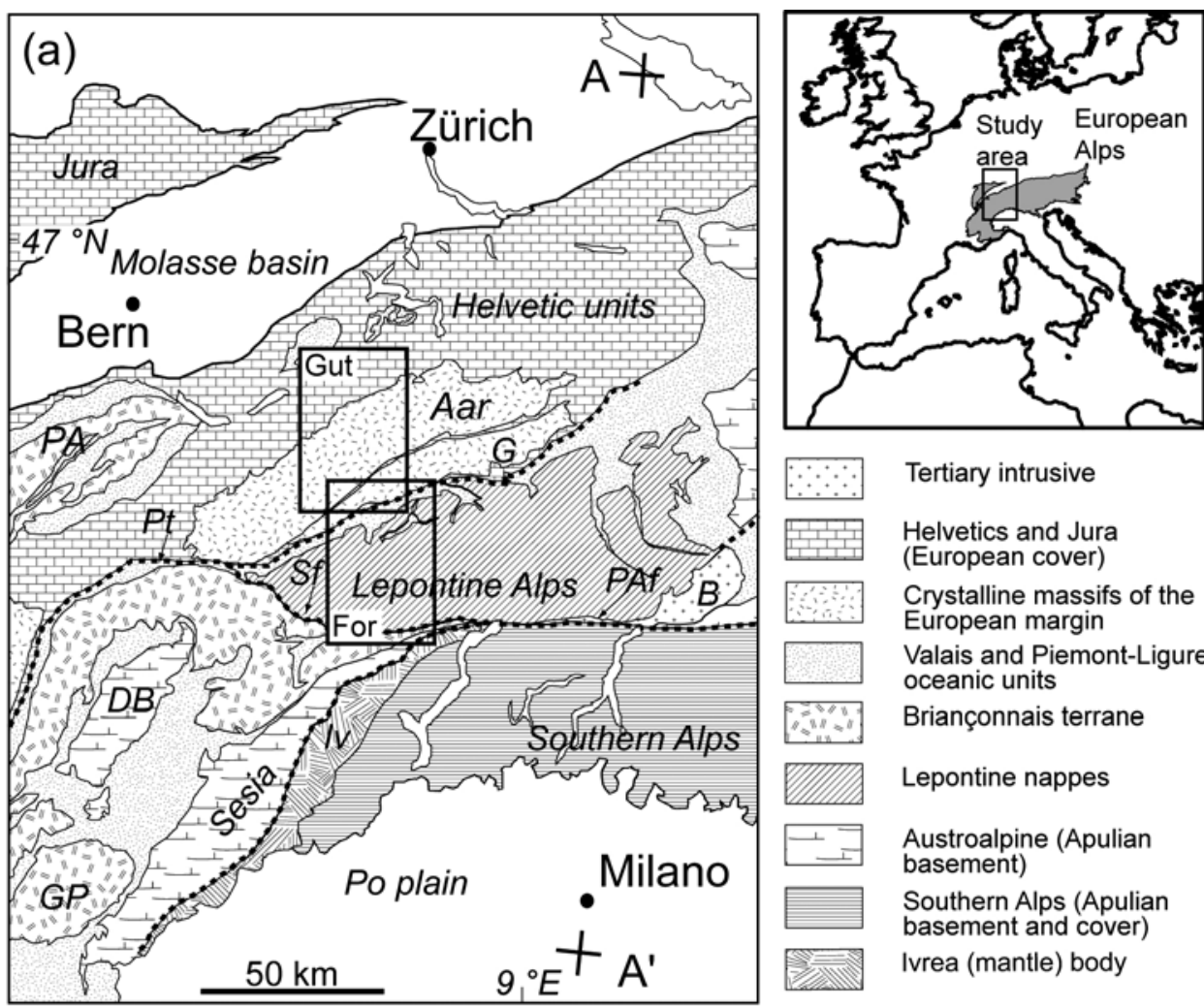

Helvetics and Jura (European cover)

Crystalline massifs of the European margin

Valais and Piemont-Ligure oceanic units

Briançonnais terrane

Lepontine nappes

Austroalpine (Apulian basement)

Southern Alps (Apulian basement and cover)

Ivrea (mantle) body

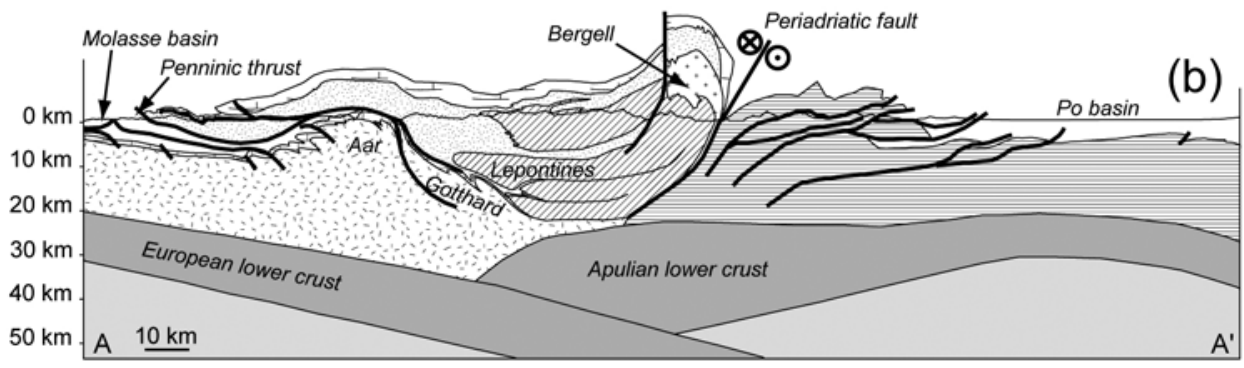

Figure 1. (a) Simplified geological map of the study area [after Schmid et al., 2004]. Abbreviations are B, Bergell; DB, Dent Blanche Massif; G, Gotthard Massif; GP, Gran Paradiso Massif; Iv, Ivrea body; PA, Prealps; PAf, Peri-Adriatic fault; Pt, Penninic thrust; Sf, Simplon fault. Inset boxes noted Gut and For represent the Guttannen (Switzerland) and the Formazza (Italy), respectively, areas used in Pecube models. (b) Crustal-scale geological cross section along the NFP20-East seismic line (A-A' in Figure 1a), showing the relationship between the main geological units [after Schmid et al., 1996].

consider the effect of apatite $\mathrm{U}$ and Th zonation on alphaejection-corrected $\mathrm{AHe}$ ages and propose that such zonation may constitute an explanation for samples where corrected AHe ages are older than AFT ages. We test several exhumation scenarios with a numerical model (Pecube) allowing us to explore the effects of temporally varying exhumation rates and evolving topography on thermochronometric age distributions [Braun, 2003]. As a result, we are able to delineate the most likely exhumation histories in the Aar Massif and Lepontine Dome and compare them with a qualitative interpretation of the AFT and AHe data from the elevation profiles. Finally, the best fit exhumation histories are compared to those required by the erosion history of the foreland basin, assuming a simple model of flexural isostatic rebound in response to accelerated erosional unloading of the axial zones [Cederbom et al., 2004].

\section{Geological Setting}

[4] Our two study areas (Figure 1) are located in the central Aar Massif (Switzerland) and the western part of the Lepontine Dome (Italy, Switzerland). This region is commonly described as belonging to the Western Alps, as defined by the boundary of the Austroalpine Silvretta unit located to the east of the Lepontine Dome [Kuhlemann, 2000]. It is bordered to the north by the Préalpes klippen, 


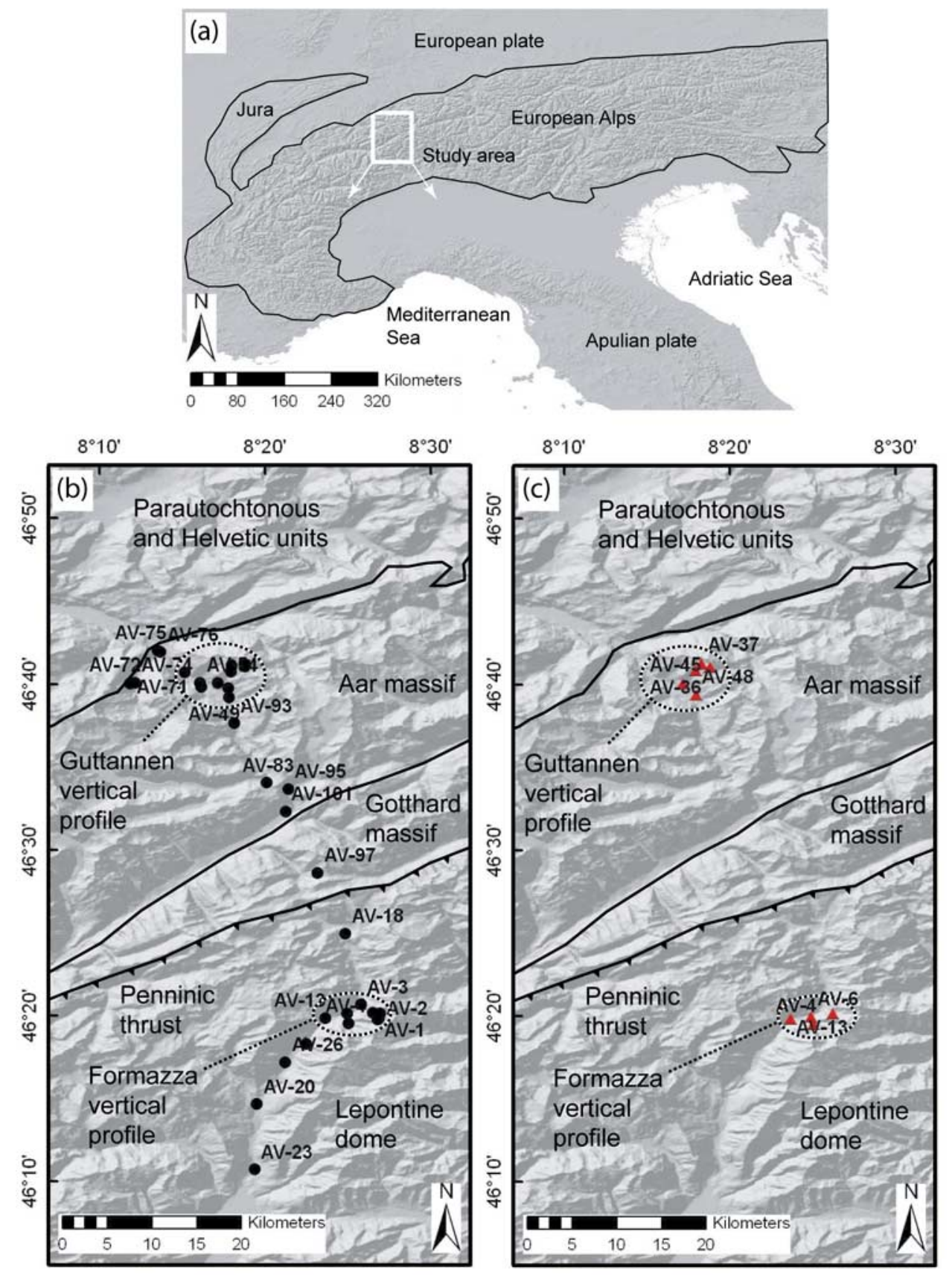

Figure 2. (a) Location map. Maps of (b) AFT and (c) AHe sampling, overlain on shaded relief model of study area (see Figure 2a for location). Main tectonic units and structures are also indicated.

Helvetic units, and perialpine sediments of the North Alpine Foreland Basin [Homewood et al., 1986]. To the south, it is bordered by the Periadriatic line, the southern Alps units and the Po plain [Schmid et al., 2004; Fantoni et al., 2004]. Whereas the North Alpine Foreland Basin has been exhuming since circa 5-4 Ma [Cederbom et al., 2004], the Po Basin accumulated post-Messinian sediments lying unconformably over the southernmost South Alpine thrusts [Fantoni et al., 2004; Scardia et al., 2006].
[5] The Aar-Gotthard Massif is one of the external crystalline massifs that expose the precollision European margin basement. They comprise pre-Variscan and Variscan metasediments, anatectic migmatites, metasedimentary and granitic gneisses, and volcanoclastic sediments [Abrecht, 1994; von Raumer et al., 1999] that strike approximately parallel to the Alps. The massifs have experienced Variscan amphibolite facies metamorphism followed by retrograde metamorphism to greenschist facies [Abrecht, 1994]. Alpine strain is 
Table 1. Sample Details ${ }^{\mathrm{a}}$

\begin{tabular}{|c|c|c|c|c|c|}
\hline Sample & Latitude & Longitude & Elevation (m) & Location & Lithology \\
\hline \multicolumn{6}{|c|}{ Guttannen Area } \\
\hline AV29 & 8.314113 & 46.68528 & 2800 & Furtwangstock & K-feldspar orthogneiss \\
\hline AV28 & 8.313765 & 46.68393 & 2720 & Furtwangstock & Orthogneiss \\
\hline AV37 & 8.305003 & 46.68782 & 2460 & Wannis lake & Orthogneiss \\
\hline AV35 & 8.300052 & 46.68471 & 2200 & Wannis lake & Orthogneiss \\
\hline AV36 & 8.29868 & 46.68068 & 2103 & Wannis lake & Orthogneiss \\
\hline AV39 & 8.299301 & 46.67865 & 2000 & Wannis lake & Orthogneiss \\
\hline AV45 & 8.286386 & 46.66772 & 1505 & Wysstanni & Orthogneiss \\
\hline AV47 & 8.296753 & 46.66225 & 1303 & Wysstanni & Micaschist \\
\hline AV48 & 8.29927 & 46.65616 & 1210 & Guttannen, Vorses & Biotite orthogneiss \\
\hline AV49 & 8.297264 & 46.65325 & 1095 & Furen & Quartzite, with epidote \\
\hline AV50 & 8.269657 & 46.66335 & 1000 & Boden & Orthogneiss \\
\hline AV54 & 8.26842 & 46.66786 & 900 & Boden & Porphyroid orthogneiss \\
\hline AV70 & 8.253222 & 46.67831 & 780 & Boden & Muscovite granitoid \\
\hline \multicolumn{6}{|c|}{ Formazza Area } \\
\hline AV1 & 8.447009 & 46.32905 & 2400 & Fondovalle & Biotite and garnet micaschist \\
\hline AV10 & 8.448012 & 46.33062 & 2280 & Fondovalle & Paragneiss \\
\hline AV2 & 8.449394 & 46.3351 & 1993 & Fondovalle & Micaschist \\
\hline AV11 & 8.441943 & 46.33607 & 1740 & Fondovalle & Porphyroid orthogneiss \\
\hline AV12 & 8.437074 & 46.33611 & 1625 & Fondovalle, Rido & Orthogneiss \\
\hline AV4 & 8.4174 & 46.32549 & 1365 & Foppiano, Alpe Croce & Deformed granitoid \\
\hline AV3 & 8.430079 & 46.34427 & 1240 & Fondovalle dorf & Deformed granitoid \\
\hline AV6 & 8.415249 & 46.33226 & 1095 & Foppiano & Paragneiss \\
\hline AV14 & 8.416279 & 46.33539 & 1020 & Alpe Cneila, new tunnel & Deformed granitoid \\
\hline AV13 & 8.394115 & 46.33064 & 895 & Chioso & Orthogneiss \\
\hline \multicolumn{6}{|c|}{$N-S$ Transect } \\
\hline AV75 & 8.225759 & 46.69964 & 640 & Innertkirchen & Deformed granitoid \\
\hline AV76 & 8.228674 & 46.69782 & 770 & Bim Chapel & Biotite orthogneiss \\
\hline AV72 & 8.200137 & 46.66766 & 1005 & Urbach Tal & Granitoid \\
\hline AV74 & 8.203077 & 46.66764 & 905 & Urbach Tal & Micaschist \\
\hline AV71 & 8.198168 & 46.667 & 1110 & Urbach Tal & Orthogneiss \\
\hline AV93 & 8.302725 & 46.62712 & 1240 & Grimsel, Schwarzbrunnenbrig & Orthogneiss \\
\hline AV83 & 8.335357 & 46.56727 & 2005 & Grimselpass & Porphyroid orthogneiss \\
\hline AV95 & 8.357095 & 46.5608 & 1790 & Gletsch & Porphyroid orthogneiss \\
\hline AV101 & 8.354433 & 46.53833 & 1405 & Oberwald, St Niklaus & Orthogneiss \\
\hline AV97 & 8.386597 & 46.47666 & 2485 & Nufenenpass & Biotite orthogneiss \\
\hline AV18 & 8.41447 & 46.41548 & 1720 & La Frua, Alpe Stafel & Micaschist \\
\hline AV16 & 8.375162 & 46.30471 & 805 & San Rocco & Orthogneiss \\
\hline AV26 & 8.354082 & 46.28621 & 760 & Cadarese & Porphyroid orthogneiss \\
\hline AV20 & 8.325497 & 46.24416 & 520 & Verampio & Granitoid \\
\hline AV23 & 8.323134 & 46.1785 & 370 & Ponte Maglio & Orthogneiss \\
\hline
\end{tabular}

${ }^{\text {a }}$ Samples ranked by decreasing elevation or from north to south. Geographical coordinates are given in datum WGS-1984.

recorded in the Aar-Gotthard Massif by the development of ductile shear fabrics, composed of broadly vertical and $\mathrm{N} 60^{\circ} \mathrm{E}$ bearing foliations and associated shear zones delimiting lenses of less deformed material [Choukroune and Gapais, 1983; Marquer and Gapais, 1985; Marquer and Burkhard, 1992].

[6] The Lepontine Dome records extensive Tertiary amphibolite facies metamorphism, delimited in the south by the Periadriatic line. To the north, metamorphic grade reduces gradually over the Penninic front, and reaches greenschist facies in the Gotthard and Aar massifs [Frey and Ferreiro Mählmann, 1999]. The Lepontine Dome is bound to the west and east by two outward dipping normal faults, the Simplon and Forcola faults, respectively. The structure of the Lepontine area is that of a pile of nappes of gneissic and metasedimentary composition pre-Triassic and Mesozoic in age, respectively [Frey and Ferreiro Mählmann, 1999]. The peak of metamorphism post-dates nappe emplacement, as isograds crosscut structural boundaries [Frey and Ferreiro Mählmann, 1999].

\section{Thermochronology}

\subsection{Sample Collection and Preparation}

[7] The Aar-Gotthard Massif and the Lepontine Dome are the sites of many of the early apatite fission track studies in the Alps, which yielded ages ranging from mid-Miocene to Pliocene [e.g., Wagner and Reimer, 1972; Schaer et al., 1975; Hurford, 1986; Michalski and Soom, 1990].

[8] Early AFT studies that estimated exhumation rates by plotting sample elevation against age commonly used transects that either followed the valleys, or that were widely dispersed. In such configurations, the slope of the ageelevation relationship (AER) may be severely overestimated, vertical or even negative, as a consequence of the fact that closure temperature isotherms are not horizontal planes 
[Stüwe et al., 1994; Mancktelow and Grasemann, 1997; Braun, 2002]. In this study, rock samples were collected along two elevation profiles perpendicular to the main valley in the Aar Massif (Guttannen locality, upper Aar valley, Switzerland) and the Lepontine Alps (Formazza locality, Toce valley, Italy), spanning 1800 and $1400 \mathrm{~m}$, respectively, of vertical relief (Figure 2 and Table 1). These two elevation profiles were completed by a north-south profile joining the two localities. Careful assessment of landforms and regional foliations at the sampled outcrops ensured that samples were from in-place bedrock and not from large deep-seated landslides. A standard mineral preparation procedure was applied; following grinding, apatites were extracted from the $80-250 \mu \mathrm{m}$ fraction by heavy liquid and magnetic techniques.

\subsection{Apatite Fission Track Dating}

[9] AFT dating was performed using the external detector method [Gleadow, 1981]. For each sample, 120 apatite crystals were handpicked under binocular lenses and molded in araldite resin, before being polished and chemically etched for $20 \mathrm{~s}$ in a $5.5 \mathrm{M} \mathrm{HNO}_{3}$ solution at $20^{\circ} \mathrm{C}$. A sheet of natural low- $U$ mica used as the induced-track detector was tightly applied against the polished surface before irradiation at the well-thermalized ORPHEE reactor in Saclay (France). NBS962 dosimeter glasses with $[\mathrm{U}]=$ $12.3 \mathrm{ppm}$ were included in the irradiation batch in order to calculate the neutron fluence. Several mineral standards (Durango and Fish Canyon apatites) were also included in order to calculate a zeta value [Hurford and Green, 1983]. Mica detectors were etched for $20 \mathrm{~min}$ in a $40 \%$ HF solution at room temperature. A total of 14 zeta measurements on Durango, Fish Canyon and Mont Dromedary apatite standards from several irradiations were used to calculate a weighted average zeta value of $325 \pm 25$. We counted spontaneous and induced tracks using a Zeiss Axioplan Fission track microscope, under $1250 \times$ magnification, with the help of reflected light to distinguish between tracks and crystal dislocations or inclusions. Provided a sufficient number of good quality apatites were present, we counted circa 20 crystals per sample, some of them without spontaneous tracks.

\subsection{Apatite (U-Th)/He (AHe) Dating}

[10] AHe dating was performed following the method described by Foeken et al. [2006] on replicates of single apatite grains carefully picked in clove oil to avoid mineral or fluid inclusion-bearing grains. The length and width of each crystal was measured under a binocular microscope under a magnification of $258 \times$ before packing in $\mathrm{Pt}$ foil tubes. The He content of single grains was extracted by heating at circa $800^{\circ} \mathrm{C}$ using a $25 \mathrm{~W}, 808 \mathrm{~nm}$ diode laser, for 2 min, purified in an ultrahigh vacuum line and measured with an electron multiplier in a Hiden HAL3F quadrupole mass spectrometer operated in static mode. Absolute $\mathrm{He}$ concentrations were calculated from peak height comparison against a known volume of ${ }^{4} \mathrm{He}$. The low He content of most samples required a blank correction which represented between 0.4 and $91 \%$ of the amount of He measured (grains with blank correction higher than $40 \%$ were later discarded; see Table 3). The same laser degassing process was repeated two or three times until reaching blank level $\mathrm{He}$, unless a continuously high amount of gas extracted suggested the presence of an unnoticed inclusion.

[11] $\mathrm{U}$ and Th were measured by isotopic dilution with inductively coupled-plasma mass spectrometry (ICP-MS). An average of $0.15 \pm 0.009 \mathrm{ng}$ of ${ }^{230} \mathrm{Th}$ and $0.06 \pm 0.003 \mathrm{ng}$ of ${ }^{235} \mathrm{U}$ were added as spike to the dissolving $5 \mathrm{M} \mathrm{HNO}_{3}$ solution and left overnight at $100^{\circ} \mathrm{C}$. ICP-MS mass fractionation was accounted for by repeated measurement of a U-500 standard. Blank measurements of nitric acid and spike were used to correct the measured isotopic ratios. The total amounts of $\mathrm{U}$ and Th were determined using the formula of Evans et al. [2005] and final AHe ages were obtained using the noniterative formula proposed by Meesters and Dunai [2005]. Durango apatites $(\mathrm{n}=4)$ yielded an average age of $32.6 \pm 0.7 \mathrm{Ma}$; within the age range (31.1 to $33.4 \mathrm{Ma}$ ) accepted by Boyce and Hodges [2005].

\section{Results}

\subsection{AFT Ages}

[12] AFT central ages were calculated using the Trackkey $4.2 \mathrm{~g}$ code [Dunkl, 2002]; the complementary use of the Binomfit peak age analysis code [Brandon, 1992, 1996] enabled detection of outlier grains, which may have an important effect on central age calculations and were thus discarded. Results are reported in Table 2 and Figure 3. In four samples, binomial peak fitting recorded two individual grain age populations representing at least $30 \%$ of the number of apatites counted (samples AV01, -54, -70, -75 ). Among these samples, one is located at the top of the Formazza profile (AV01 in Table 2) and two others at the base of the Guttannen profile (AV54, -70 in Table 2). The last sample showing this behavior, AV75, is located at a lower elevation than the Guttannen profile sensu stricto, further down the valley. All samples are from basement rocks having undergone alpine metamorphism in greenschist or higher facies, which affected most parts of the Aar and Lepontine massifs [Hunziker et al., 1992; Challandes, 2001]. Although these conditions must have reset all lowtemperature thermochronometers, a range of apatite composition in metasediments affects the closure temperature of each grain [e.g., O'Sullivan and Parrish, 1995], thus leading to several groups of single-grain ages within a sample. This effect is stronger in the case of an extended stay in the temperature range corresponding to the AFT partial annealing zone. Unfortunately, the overall low numbers of spontaneous tracks in the analyzed apatites rendered the quantification of track length distributions and subsequent modeling of the cooling histories impossible.

[13] AFT ages for samples from the Guttannen and Formazza elevation profiles are plotted in Figure 4, discarding samples with two major grain age populations. The ages used are either the central age, or the main peak age (P1 age in Table 2) in case of the presence of a few outlier grains. Uncertainty-weighted regression lines and 95\% confidence intervals are added to the diagrams, along with the slope of 
Table 2. AFT Dating Results ${ }^{\mathrm{a}}$

\begin{tabular}{|c|c|c|c|c|c|c|c|c|c|c|c|c|c|c|c|c|c|c|c|}
\hline Sample & $\mathrm{N}$ & $\rho_{\mathrm{s}}$ & $\mathrm{N}_{\mathrm{s}}$ & $\rho_{\mathrm{i}}$ & $\mathrm{N}_{\mathrm{i}}$ & $\rho_{\mathrm{d}}$ & $\mathrm{N}_{\mathrm{d}}$ & $\mathrm{P}\left(\chi^{2}\right)$ & $\mathrm{D}$ & Age & Age $1 \sigma$ & $\begin{array}{c}\text { P1 } \\
\text { Age }\end{array}$ & $\begin{array}{c}\text { P1 } \\
\text { Age } 1 \sigma\end{array}$ & $\mathrm{P} 1 \%$ & $\begin{array}{c}\text { P2 } \\
\text { Age }\end{array}$ & $\begin{array}{c}\text { P2 } \\
\text { Age } 1 \sigma\end{array}$ & $\mathrm{P} 2 \%$ & {$[\mathrm{U}]$} & $\Delta[\mathrm{U}]$ \\
\hline \multicolumn{20}{|c|}{ Guttannen Section } \\
\hline AV29 & 22 & 3.24 & 463 & 31.93 & 4558 & 5.302 & 9317 & 68.6 & 0 & 8.7 & 0.8 & 8.7 & 0.8 & 100 & & & & 74 & 29 \\
\hline AV28 & 22 & 1.35 & 246 & 13.89 & 2534 & 5.492 & 7546 & 58.2 & 6 & 8.7 & 0.9 & 8.7 & 0.9 & 100 & & & & 33 & 61 \\
\hline AV35 & 22 & 4.79 & 919 & 49.49 & 9490 & 5.491 & 7546 & 0.2 & 16 & 8.7 & 0.8 & 8.3 & 0.8 & 93.2 & 14.6 & 4.1 & 6.8 & 112 & 31 \\
\hline AV39 & 22 & 5.03 & 937 & 51.89 & 9666 & 5.491 & 7546 & 17.3 & 7 & 8.6 & 0.7 & 8.4 & 0.8 & 93.3 & 12.9 & 3.1 & 0.7 & 116 & 18 \\
\hline AV45 & 21 & 4.44 & 586 & 54.97 & 7252 & 5.240 & 7463 & 72.1 & 0 & 6.9 & 0.6 & 6.9 & 0.6 & 100 & & & & 129 & 22 \\
\hline AV47 & 22 & 3.97 & 438 & 52.60 & 5797 & 5.490 & 7546 & 65.9 & 0 & 6.7 & 0.6 & 6.7 & 0.7 & 100 & & & & 118 & 23 \\
\hline AV49 & 7 & 1.2 & 63 & 13.1 & 679 & 5.490 & 7546 & 81.4 & 0 & 8.3 & 1.3 & 8.3 & 1.3 & 100 & & & & 29 & 27 \\
\hline AV50 & 22 & 3.90 & 511 & 49.66 & 6515 & 5.810 & 9647 & 51.6 & 8 & 7.4 & 0.7 & 7.7 & 0.8 & 93.3 & 4.7 & 1.25 & 6.7 & 103 & 28 \\
\hline AV $54^{\mathrm{b}}$ & 21 & 2.78 & 320 & 41.44 & 4776 & 5.489 & 7546 & 3.7 & 18 & 6.1 & 0.6 & 7.1 & 1.2 & 61 & 4.7 & 1 & 39 & 91 & 25 \\
\hline $\mathrm{AV} 70^{\mathrm{b}}$ & 19 & 4.38 & 465 & 54.56 & 5797 & 5.489 & 7546 & 4.6 & 16 & 7.3 & 0.7 & 8.2 & 1.0 & 70 & 5.4 & 0.85 & 30 & 123 & 42 \\
\hline \multicolumn{20}{|c|}{ Formazza Section } \\
\hline $\mathrm{AV} 1^{\mathrm{b}}$ & 23 & 0.48 & 68 & 6.75 & 959 & 5.310 & 9317 & 19.3 & 30 & 6.2 & 1 & 7.7 & 2.2 & 69.4 & 3.2 & 2.1 & 30.6 & 16 & 31 \\
\hline AV10 & 22 & 0.45 & 66 & 9.075 & 1338 & 5.495 & 7546 & 16.3 & 28 & 4.5 & 0.7 & 3.6 & 0.9 & 80.5 & 8.4 & 4.3 & 19.5 & 21 & 56 \\
\hline AV2 & 21 & 0.43 & 60 & 8.332 & 1175 & 5.496 & 7546 & 53.0 & 3 & 4.6 & 0.7 & 4.6 & 0.7 & 100 & & & & 18 & 38 \\
\hline AV11 & 16 & 0.42 & 32 & 11.2 & 855 & 5.813 & 9647 & 65.1 & 11 & 3.5 & 0.7 & 3.5 & 0.7 & 100 & & & & 23 & 63 \\
\hline AV4 & 21 & 0.37 & 55 & 6.62 & 976 & 5.496 & 7546 & 0.2 & 50 & 5.1 & 1 & 4.7 & 0.8 & 95.5 & 46.9 & 40.95 & 4.5 & 14 & 65 \\
\hline AV3 & 20 & 0.34 & 42 & 8.020 & 1004 & 5.496 & 7546 & 65.7 & 2 & 3.7 & 0.7 & 3.7 & 0.7 & 100 & & & & 17 & 41 \\
\hline AV14 & 20 & 0.38 & 34 & 8.01 & 715 & 5.812 & 9647 & 66.2 & 3 & 4.5 & 0.9 & 4.5 & 0.9 & 100 & & & & 17 & 42 \\
\hline AV13 & 21 & 0.41 & 59 & 7.632 & 1091 & 5.495 & 7546 & 76.1 & 0 & 4.8 & 0.7 & 4.8 & 0.8 & 100 & & & & 18 & 46 \\
\hline \multicolumn{20}{|c|}{$N-S$ Transect } \\
\hline $\mathrm{AV} 75^{\mathrm{b}}$ & 20 & 1.85 & 316 & 22.66 & 3876 & 5.810 & 9647 & 13.3 & 15 & 7.7 & 0.8 & 6.8 & 1.1 & 67.1 & 9.6 & 2.25 & 32.9 & 48 & 21 \\
\hline AV76 & 20 & 5.29 & 655 & 57.58 & 7128 & 5.270 & 7463 & 0.1 & 9 & 7.9 & 0.8 & 7.6 & 0.7 & 80.1 & 11.9 & 1.75 & 14.7 & 133 & 36 \\
\hline AV72 & 6 & 2.3 & 59 & 31.8 & 814 & 5.286 & 7463 & 30.9 & 6 & 6.2 & 1 & 6.2 & 1.0 & 100 & & & & 71 & 36 \\
\hline AV74 & 21 & 2.16 & 322 & 30.70 & 4572 & 5.810 & 9647 & 57.4 & 2 & 6.6 & 0.6 & 6.6 & 0.7 & 100 & & & & 65 & 25 \\
\hline AV71 & 19 & 3.63 & 368 & 44.82 & 4542 & 5.278 & 9317 & 45.6 & 4 & 6.9 & 0.7 & 6.8 & 0.7 & 94 & 10.3 & 4.7 & 6 & 113 & 43 \\
\hline AV93 & 6 & 0.44 & 12 & 5.25 & 142 & 5.317 & 7463 & 52.3 & 0 & 7.3 & 2.3 & 7.3 & 2.3 & 100 & & & & 12 & 38 \\
\hline AV83 & 10 & 0.66 & 33 & 7.14 & 359 & 5.301 & 7463 & 95.8 & 0 & 7.9 & 1.6 & 7.9 & 1.6 & 100 & & & & 20 & 70 \\
\hline AV95 & 17 & 1.12 & 102 & 14.85 & 1349 & 5.811 & 9647 & 72.4 & 2 & 7.1 & 0.9 & 7.1 & 0.95 & 100 & & & & 31 & 47 \\
\hline AV101 & 15 & 2.8 & 88 & 55.48 & 1769 & 5.378 & 7463 & 0.3 & 49 & 4.6 & 0.9 & 3.6 & 1.0 & 86 & 11 & 4.05 & 14 & 112 & 59 \\
\hline AV97 & 25 & 0.41 & 77 & 5.867 & 1093 & 5.332 & 7463 & 6.7 & 6 & 6.1 & 0.9 & 6 & 1.0 & 97.9 & 20.7 & 58 & 2.1 & 13 & 48 \\
\hline AV18 & 20 & 0.44 & 58 & 6.16 & 807 & 5.494 & 7546 & 58.8 & 0 & 6.4 & 1 & 6.4 & 1.0 & 100 & & & & 13 & 64 \\
\hline AV16 & 17 & 0.49 & 62 & 12.86 & 1623 & 5.494 & 7546 & 94.2 & 0 & 3.4 & 0.5 & 3.4 & 0.6 & 100 & & & & 28 & 50 \\
\hline AV26 & 23 & 0.19 & 29 & 6.785 & 1049 & 5.492 & 7546 & 7.0 & 37 & 2.5 & 0.5 & 3.1 & 1 & 79.9 & 0.3 & 9.2 & 20.1 & 15 & 54 \\
\hline AV20 & 21 & 0.12 & 21 & 2.62 & 446 & 5.493 & 7546 & 45.0 & 51 & 4.1 & 1.1 & 3 & 1.1 & 85.8 & 10.2 & 6.55 & 14.2 & 6 & 72 \\
\hline AV23 & 25 & 0.24 & 57 & 5.435 & 1320 & 5.492 & 7546 & 81.0 & 2 & 3.9 & 0.6 & 3.9 & 3.9 & 100 & & & & 12 & 34 \\
\hline
\end{tabular}

${ }^{\mathrm{a}} \mathrm{N}$, number of apatite grains counted; $\rho_{\mathrm{s}}$, density of spontaneous tracks $\left(10^{5} / \mathrm{cm}^{2}\right) ; \mathrm{N}_{\mathrm{s}}$, number of spontaneous tracks; $\rho_{\mathrm{i}}$, density of induced tracks $\left(10^{5} / \mathrm{cm}^{2}\right)$; $\mathrm{N}_{\mathrm{i}}$, number of induced tracks; $\rho_{\mathrm{d}}$, density of tracks on irradiation fluence dosimeters $\left(10^{5} / \mathrm{cm}^{2}\right) ; \mathrm{N}_{\mathrm{d}}$, number of tracks counted on irradiation fluence dosimeters; $\mathrm{P}\left(\chi^{2}\right)$, probability that the single-grain ages represent one population (\%); $\mathrm{D}$, age dispersion (\%); Age, central age (Ma); $1 \sigma$, uncertainty on central age (Ma); P1 age, major age component in grains age peak analysis (Ma); P1\%, percentage of total number of grains in main age peak; P2 age, minor age component in grains age peak analysis (Ma); P2\%, percentage of total number of grains in minor age peak; [U], uranium concentration (ppm); $\Delta[\mathrm{U}]$, uncertainty on uranium concentration (\%). Samples are ranked in decreasing elevation order within the Guttannen and Formazza sections and from north to south in N-S transect.

${ }^{\mathrm{b}}$ Sample with multiple age populations.

the regression line, which corresponds to the apparent exhumation rate. We performed the age-elevation regression following the method of Williamson [1968], with none of the parameters considered as independent. The errors used for AFT ages are the $1 \sigma$ uncertainty on the central age or main peak age.

[14] Central ages in the Guttannen elevation profile show a positive correlation with elevation (Figure 4), with ages varying from $6.7 \pm 0.6 \mathrm{Ma}$ at $1303 \mathrm{~m}$ (AV47) to $8.7 \pm$ $0.8 \mathrm{Ma}$ at $2800 \mathrm{~m}$ elevation (AV29). The regression relationship is very steep, with an apparent exhumation rate of $1028 \pm 459 \mathrm{~m} / \mathrm{Ma}$, based on an uncertainty-weighted regression calculation with $\mathrm{r}^{2}=0.43$.

[15] Central ages in the Formazza elevation profile are inversely correlated with elevation (Figure 4) and vary between $3.5 \pm 0.7$ (AV11) and $5.1 \pm 1.0$ (AV4) Ma, i.e., significantly younger than in the Guttannen profile. The relatively poorly constrained AER of $-1966 \pm 2309 \mathrm{~m} / \mathrm{Ma}$ does not rule out a positive apparent exhumation rate of $>1200 \mathrm{~m} / \mathrm{Ma}$ at the $95 \%$ confidence level. Negative AERs can also occur when local tilting of the profile has occurred since closure [Rahn and Grasemann, 1999], or in large valleys when the topographic slope is modified by relief reduction and becomes less steep than the AFT closure surface [Braun, 2002].

[16] A profile of AFT central ages along a N-S transect (Figure 3) illustrates a pattern of older ages over the Aar Massif (Guttannen elevation profile) than over the Lepontine Alps (Formazza profile), with ages around 8-7 Ma and 5-4 Ma, respectively. The ages on the horizontal transect are in agreement with existing data from Keller et al. [2005] in the western Lepontine Alps or Schaer et al. [1975] and 
(a)
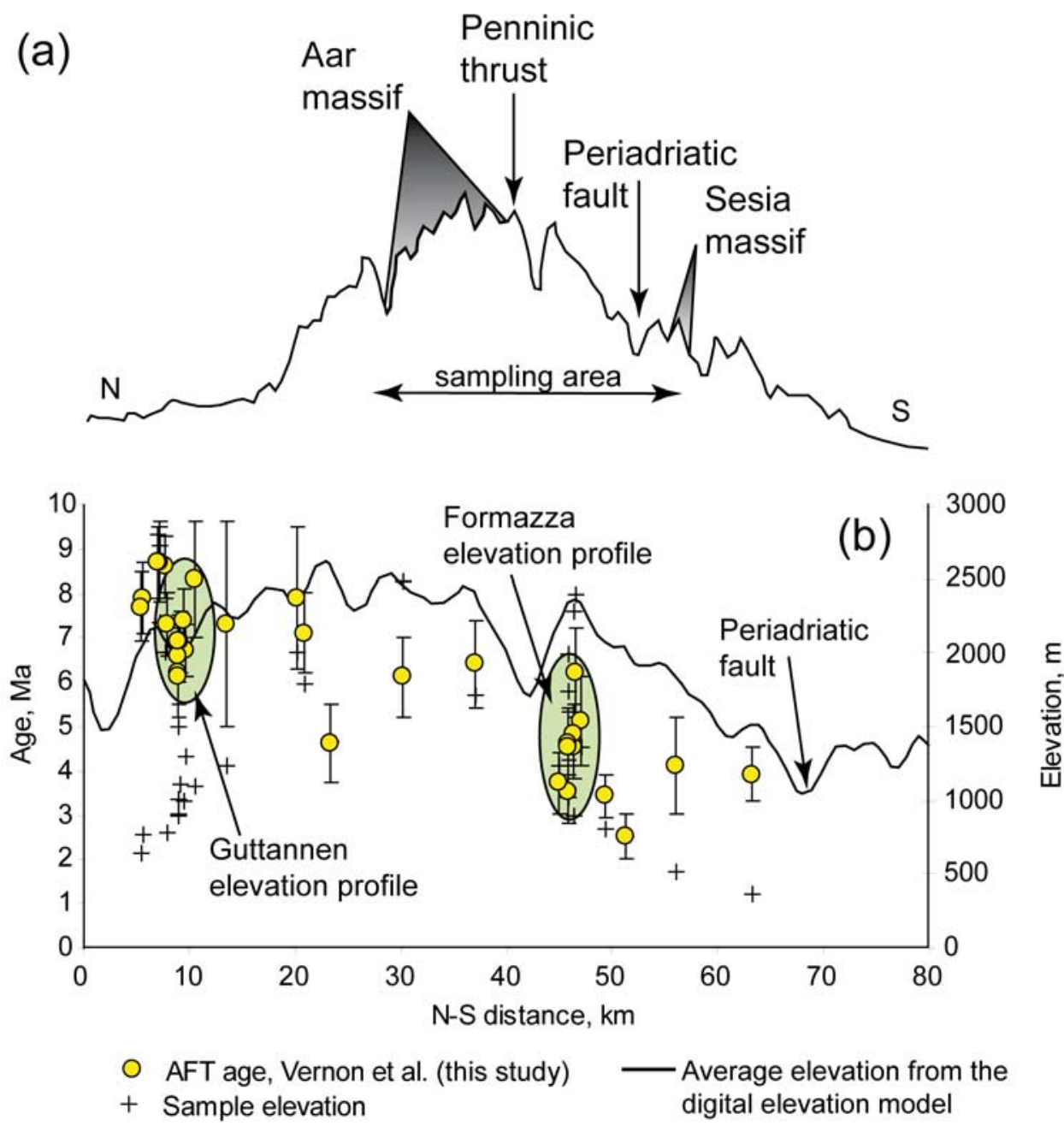

Figure 3. (a) Longitudinal profile of AFT ages. Projection of central AFT ages (circles) obtained in this study on a north-south average topographic cross section joining the Guttannen elevation profile (Switzerland) to the Formazza elevation profile (Italy). (b) A close-up on the sampling area indicated on Figure 3a. Vertical error bars show the $1 \sigma$ uncertainty on central ages, and crosses show the sample elevation (see Tables 1 and 2). AFT central ages are significantly younger for the Formazza elevation profile than for the Guttannen profile.

Rahn and Grasemann [1999] in the northeastern AarGotthard Massif. AFT ages published by Michalski and Soom [1990] for the upper Aar valley upstream and downstream of our elevation profile $(12.0 \pm 0.9 \mathrm{Ma}$ at $720 \mathrm{~m}$, $4.2 \pm 1.1 \mathrm{Ma}$ at $1586 \mathrm{~m}$ and $5.3 \pm 1.1 \mathrm{Ma}$ at $2160 \mathrm{~m}$ ) differ from our measurements; however part of the difference may be explained by the relatively low number of spontaneous tracks counted in both studies, and by the lack of good quality apatites.

\subsection{AHe Ages}

[17] The results for three to five single-crystal replicates for each sample are reported in Table 3. However, we discarded results of several replicates, for reasons detailed in the legend of Table 3, prior to the calculation of uncertainty-weighted average ages (Figure 5).
[18] The age-elevation relationships of uncorrected $\mathrm{AHe}$ ages in the Guttannen and the Formazza elevation profiles are presented in Figure 6, using the same method of regression line calculation as described in section 4.1. The justification for using uncorrected ages is outlined in detail in sections 4.3 and 4.4. The Guttannen profile displays a strongly correlated relationship with elevation $\left(r^{2}=0.88\right)$ with weighted-mean ages ranging from $5.2 \pm 0.5 \mathrm{Ma}$ at $1505 \mathrm{~m}$ elevation (AV45) to $9.0 \pm 1.3 \mathrm{Ma}$ at $2720 \mathrm{~m}$ (AV28), and an apparent exhumation rate of $486 \pm 135 \mathrm{~m} / \mathrm{Ma}$. In Formazza, the age-elevation relationship is steeper (apparent exhumation rate of $675 \pm 539 \mathrm{~m} / \mathrm{Ma}$ ) but less well constrained $\left(r^{2}=0.5\right)$. Weighted average AHe ages are also younger, ranging from $2.6 \pm 0.2 \mathrm{Ma}$ at $895 \mathrm{~m}$ elevation (AV13) to $5.2 \pm 2.5 \mathrm{Ma}$ at $1625 \mathrm{~m}$ (AV12). 


\section{Guttannen profile}

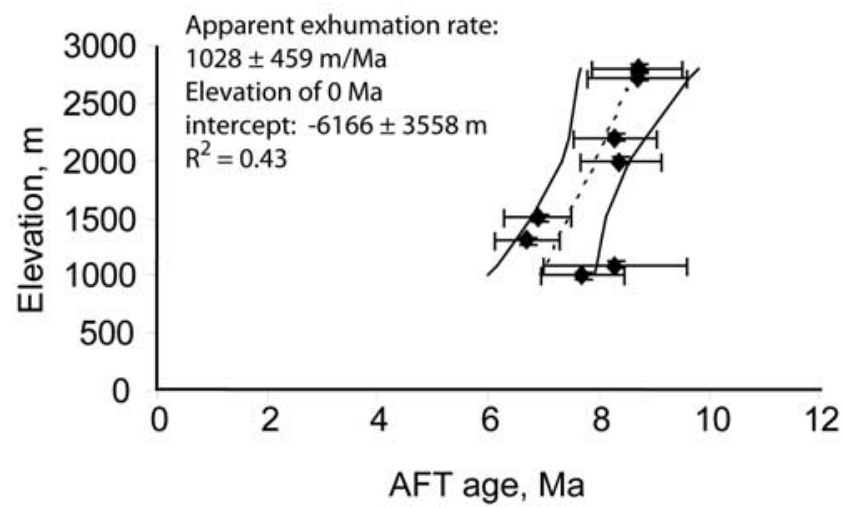

\section{Formazza profile}

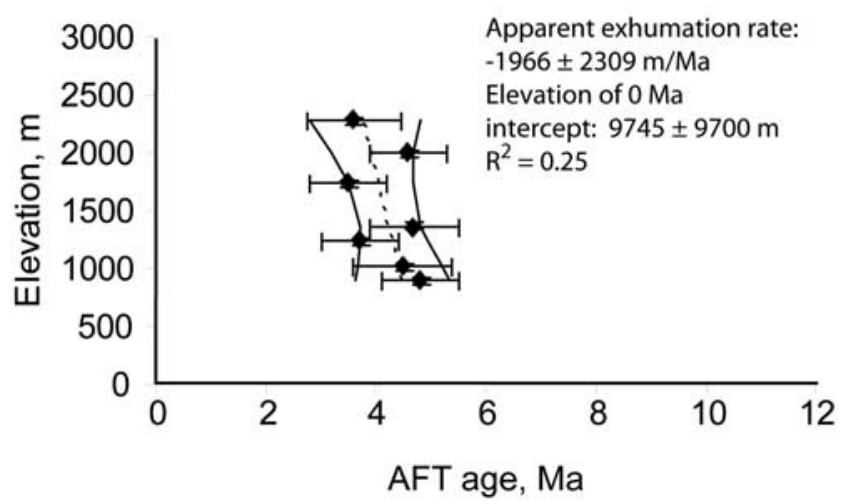

Figure 4. AFT age-elevation profiles and weighted regression relationship (dashed line, regression line; bold lines, 95\% confidence interval) for the Guttannen and the Formazza areas. Central ages or main age peak of the AFT age population are plotted with $1 \sigma$ error bars, excluding samples with a second age peak population comprising more than $30 \%$ of the grains counted (AV1, AV54, and AV70).

\subsection{Alpha Ejection Correction}

[19] In samples with homogeneous $U$ and Th distributions, a significant amount of He is lost by radioactive decay of atoms situated close to the crystal border. The proportion of He loss out of the crystal during the emission of alpha particles decreases from $50 \%$ on the grain surface to zero when the emission point is located more than $20 \mu \mathrm{m}$ from the surface [Farley et al., 1996; Farley, 2002]. A correction factor $\left(F_{t}\right)$ based on crystal shape and $\mathrm{Th} / \mathrm{U}$ ratio therefore needs to be applied to unzoned grains, following the method of Farley [2002], in order to make up for the lost He and avoid age underestimation. However, the determination of the grain surface/volume ratio is imprecise and the error on the correction factor $\mathrm{Ft}$ is particularly important for small grains [Farley et al., 1996].
[20] The distinctive closure temperatures usually considered for the AFT and AHe thermochronometers $\left(120-90^{\circ} \mathrm{C}\right.$ and $80-55^{\circ} \mathrm{C}$, respectively [Reiners et al., 2005]), lead us to expect AFT ages to be older than AHe ages at a given location. However, several of our corrected AHe ages overlap with, or are older than the AFT ages of the same samples (e.g., AV28 and AV45), or of samples located at similar elevations on an elevation profile (see Figure 7).

\subsection{Modeling the Role of Apatite Zoning on AHe Age}

[21] Various factors, such as the underestimation of fission track annealing [e.g., Hendriks and Redfield, 2005], or the overestimation of He diffusion [Green et al., 2006; Shuster et al., 2006] in radiation-damaged apatite may explain overlap between AHe and AFT ages, particularly in U-rich or old samples. Neither condition, however, is met by our samples. An alternative explanation could be overcorrection of AHe ages by the alpha ejection parameter due to $\mathrm{U}$ and Th zonation [Meesters and Dunai, 2002b; Boyce and Hodges, 2005; Hourigan et al., 2005; Herman et al., 2007]. The correction is underestimated if $U$ and $T h$ are concentrated in the outer $20 \mu \mathrm{m}$ (external zoning), and overestimated if the outer $20 \mu \mathrm{m}$ is depleted (internal zoning). Additionally, the $\mathrm{F}_{\mathrm{t}}$ correction assumes that the minerals surrounding the apatite grain are devoid of $U$ and Th, whereas in natural rocks several minerals, such as micas, have $\mathrm{U}$ and $\mathrm{Th}$ concentrations equal to or larger than apatite, which may lead to He implantation in the outer $20 \mu \mathrm{m}$ of the grain [Spencer et al., 2004].

[22] Strong zoning in induced-track density was observed in apatite grains for several AFT samples (Figure 8). For instance, samples AV2, AV4 or AV13 strikingly displayed prints of induced tracks smaller than the crystal size, suggesting internal zoning. In these conditions, the real AHe age of a crystal would lie between the raw and the corrected values. We assess the effect of $U$ zoning using a Monte Carlo model of He loss out of a crystal or realistic shape with an arbitrary U/Th distribution, developed by Gautheron et al. [2008]. Results for crystal shapes, U zoning and $\mathrm{U} / \mathrm{Th}$ ratios that are characteristic of the apatites in our study, suggest that "standard" Ft correction factors of $0.62-0.84$ determined for our samples severely overestimate the correction: for an $80 \%$ depleted, $30-\mu \mathrm{m}$-wide rim the Ft correction factor should be $\geq 0.9$ and it becomes negligibly close to 1 for $90 \%$ depleted rims.

[23] We also use the forward model Decomp [Meesters and Dunai, 2002a, 2002b; Dunai, 2005] to illustrate the effect of cooling history and U-Th zoning on the AHe ages. The algorithm takes into consideration alpha ejection from the external part of the crystals and He diffusion out of the grains, both of which strongly depend on $U$ and Th zoning. In order to assess the extent to which the age variation measured in several replicates could be due to zoning, we modeled the effect of zoning on apparent AHe ages for several realistic cooling history scenarios with rates between 8 and $25^{\circ} \mathrm{C} / \mathrm{Ma}$ (Figure 9). The model apatite used is a sphere of $75 \mu \mathrm{m}$ radius, which corresponds to the mean surface/volume ratio observed in the crystals we dated in 
Table 3. AHe Dating Results ${ }^{\mathrm{a}}$

\begin{tabular}{|c|c|c|c|c|c|c|c|c|c|c|c|c|c|c|c|c|c|c|c|c|}
\hline Sample & ${ }^{232} \mathrm{Th}$ & ${ }^{232}$ Th $1 \sigma$ & ${ }^{238} \mathrm{U}$ & ${ }^{238} \mathrm{U} 1 \sigma$ & ${ }^{4} \mathrm{He}$ & ${ }^{4} \mathrm{He} 1 \sigma$ & $\begin{array}{l}\text { TA } \\
\text { Error }\end{array}$ & $\begin{array}{l}\text { Raw } \\
\text { Age }\end{array}$ & $\begin{array}{c}1 \sigma \\
\text { Raw } \\
\text { Age } \\
\text { Error }\end{array}$ & $\mathrm{L}$ & W & $\operatorname{Tr}$ & $\mathrm{F}_{\mathrm{t}}$ & $\begin{array}{l}\text { Corr } \\
\text { Age }\end{array}$ & $\begin{array}{c}1 \sigma \\
\text { Corr } \\
\text { Age } \\
\text { Error }\end{array}$ & Use & $\begin{array}{l}\text { WR } \\
\text { Age }\end{array}$ & $\begin{array}{c}\text { WR } \\
\text { Error }\end{array}$ & $\begin{array}{l}\text { WC } \\
\text { Age }\end{array}$ & $\begin{array}{l}\text { WC } \\
\text { Error }\end{array}$ \\
\hline \multicolumn{21}{|c|}{ Guttannen Section } \\
\hline AV28-1 & 0.035 & 0.002 & 0.106 & 0.006 & $1.15 \times 10^{-10}$ & $6.15 \times 10^{-13}$ & 8.6 & 8.3 & 0.7 & 235 & 150 & 2 & 0.81 & 10.3 & 0.9 & A & & & & \\
\hline AV28-2 & 0.022 & 0.002 & 0.124 & 0.007 & $2.38 \times 10^{-10}$ & $1.30 \times 10^{-12}$ & 8.7 & 15.1 & 1.3 & 245 & 135 & 2 & 0.79 & 19.0 & 1.7 & A & & & & \\
\hline AV28-3 & 0.071 & 0.005 & 0.116 & 0.007 & $1.23 \times 10^{-10}$ & $4.74 \times 10^{-13}$ & 8.5 & 7.6 & 0.7 & 200 & 160 & 1 & 0.82 & 9.3 & 0.8 & Y & & & & \\
\hline $28-4$ & 0.019 & 0.001 & 0.111 & 0.007 & $1.21 \times 10^{-10}$ & $4.57 \times 10^{-13}$ & 9.1 & 8.6 & 0.8 & 225 & 145 & 1 & 0.81 & 10.6 & 1.0 & Y & & & & \\
\hline AV28-5 & 0.024 & 0.002 & 0.110 & 0.006 & $1.51 \times 10^{-10}$ & $5.94 \times 10^{-13}$ & 8.5 & 10.7 & 0.9 & 225 & 150 & 2 & 0.80 & 13.3 & 1.1 & $\mathrm{Y}$ & 9.0 & 1.3 & 11.1 & 1.7 \\
\hline V37-1 & 0.024 & 0.002 & 0.468 & 0.026 & $99 \times 10^{-10}$ & $1.85 \times 1$ & 8.8 & 8.7 & 0.8 & 185 & 175 & 0 & 0.84 & 10.3 & 0.9 & Y & & & & \\
\hline AV37-2 & 0.007 & 0.001 & 0.199 & 0.011 & $1.87 \times 10^{-10}$ & $7.09 \times 10^{-13}$ & 9.4 & 7.7 & 0.7 & 200 & 150 & 1 & 0.82 & 9.4 & 0.9 & Y & & & & \\
\hline AV37-3 & 0.038 & 0.002 & 0.168 & 0.009 & $1.57 \times 10^{-10}$ & $5.85 \times 10^{-13}$ & 8.3 & 7.3 & 0.6 & 195 & 135 & 2 & 0.78 & 9.4 & 0.8 & Y & & & & \\
\hline AV37-4 & 0.013 & 0.001 & 0.252 & 0.016 & $2.64 \times 10^{-10}$ & $1.02 \times 10^{-12}$ & 9.5 & 8.5 & 0.8 & 220 & 155 & 1 & 0.82 & 10.3 & 1.0 & Y & 8.0 & 0.7 & 9.8 & 0.9 \\
\hline V36-1 & 0.048 & 0.003 & 0.102 & .006 & 10 & $4.57>$ & 8.6 & 7.6 & 0.7 & 265 & 125 & 2 & 0.78 & 9.8 & 0.8 & Y & & & & \\
\hline $36-2$ & 0.047 & 0.003 & 0.059 & 0.004 & $5.38 \times$ & $2.15 \times 10^{-13}$ & 9.5 & 6.3 & 0.6 & 140 & 65 & 1 & 0.62 & 10.2 & 1.0 & Y & & & & \\
\hline $36-3$ & 0.026 & 0.002 & 0.073 & 0.005 & $75 \times 10^{-11}$ & $2.69 \times 10^{-13}$ & 9.3 & 7.0 & 0.7 & 170 & 125 & 2 & 0.76 & 9.2 & 0.9 & Y & & & & \\
\hline AV36-4 & 0.040 & 0.002 & 0.056 & 0.003 & $5.64 \times 10^{-11}$ & $2.25 \times 10^{-13}$ & 8.3 & 7.1 & 0.6 & 160 & 130 & 2 & 0.76 & 9.3 & 0.8 & Y & & & & \\
\hline AV36-5 & 0.140 & 0.008 & 0.109 & 0.006 & $3.27 \times 10^{-10}$ & $1.31 \times 10^{-12}$ & 8.2 & 18.9 & 1.6 & 215 & 130 & 2 & 0.78 & 24.4 & 2.0 & D & 7.1 & 0.6 & 9.6 & 0.9 \\
\hline V45-1 & 009 & 0 & 0.228 & 0.013 & $0^{-10}$ & -13 & & 5.0 & 0.4 & 55 & 105 & 2 & 73 & 8 & 0 & Y & & & & \\
\hline AV45-2 & 0.013 & 0.001 & 0.259 & 0.015 & $1.70 \times 10^{-10}$ & $7.41 \times 10^{-13}$ & 10.0 & 5.3 & 0.5 & 150 & 100 & 1 & 0.74 & 7.2 & 0.7 & Y & & & & \\
\hline AV45-3 & 0.010 & 0.001 & 0.213 & 0.011 & $1.26 \times 10^{-10}$ & $5.59 \times 10^{-13}$ & 9.1 & 4.8 & 0.4 & 215 & 70 & 0 & 0.67 & 7.2 & 0.7 & $\mathrm{Y}$ & & & & \\
\hline AV45-4 & 0.013 & 0.001 & 0.182 & 0.010 & $1.03 \times 10^{-10}$ & $4.55 \times 10^{-13}$ & 9.9 & 4.6 & 0.5 & 150 & 75 & 0 & 0.68 & 6.7 & 0.7 & Y & & & & \\
\hline AV45-5 & 0.018 & 0.001 & 0.256 & 0.014 & $1.92 \times 10^{-10}$ & $7.57 \times 10^{-13}$ & 9.1 & 6.1 & 0.6 & 175 & 100 & 1 & 0.74 & 8.2 & 0.7 & $\mathrm{Y}$ & 5.2 & 0.5 & 7.2 & 0.7 \\
\hline V48-1 & 0.016 & 0 & 1.086 & 58 & $48 \times 10^{-10}$ & $3.18 \times 10^{-12}$ & 9.1 & 6.4 & 0.6 & 200 & 150 & 2 & 0.80 & 8.0 & 0.7 & Y & & & & \\
\hline AV48-2 & 0.007 & 0.001 & 0.664 & .035 & $59 \times 10^{-10}$ & $1.80 \times 10^{-12}$ & 8.8 & 5.7 & 0.5 & 185 & 125 & 2 & 0.77 & 7.4 & 0.7 & Y & & & & \\
\hline $48-3$ & 0.006 & 0 & 0.407 & 23 & -10 & $1.07 \times$ & 9.0 & 5.4 & 0.5 & 190 & 125 & 1 & 0.79 & 6.9 & 0.6 & Y & & & & \\
\hline V48-4 & 0.011 & 001 & 0.870 & .050 & $6.56 \times 10^{-10}$ & $2.61 \times 10^{-12}$ & 9.3 & 6.2 & 0.6 & 210 & 170 & 0 & 0.84 & 7.3 & 0.67 & Y & & & & \\
\hline AV48-5 & 0.026 & 0.002 & 0.312 & 0.018 & $1.63 \times 10^{-10}$ & $6.51 \times 10^{-13}$ & 8.9 & 4.2 & 0.4 & 190 & 155 & 1 & 0.82 & 5.1 & 0.5 & Y & 5.9 & 0.5 & 7.4 & 0.7 \\
\hline \multicolumn{21}{|c|}{ Formazza Section } \\
\hline V12-1 & 0.016 & 0.001 & 0.275 & 016 & $5.72 \times 1$ & $2.64 \times$ & 8.7 & 0.2 & 0.0 & 240 & 150 & 2 & 0.81 & 0.2 & 0.0 & D & & & & \\
\hline $12-2$ & 005 & 0 & 0.005 & 001 & -13 & $4.49>$ & 15.2 & 1.2 & 0.2 & 0 & 100 & 2 & 0.72 & 1.7 & 0.3 & $\mathrm{~B}, \mathrm{C}$ & & & & \\
\hline $12-3$ & 0.000 & 0.000 & 0.005 & 0.001 & -12 & $2.22 \times 10^{-14}$ & 32.1 & 7.4 & 2.4 & 225 & 140 & 2 & 0.80 & 9.3 & 3.0 & $\mathrm{C}$ & & & & \\
\hline AV12-4 & 0.032 & 0.002 & 0.033 & 0.002 & $1.47 \times 10^{-11}$ & $7.02 \times 10^{-14}$ & 10.0 & 3.0 & 0.3 & 220 & 150 & 1 & 0.81 & 3.6 & 0.4 & Y & & & & \\
\hline AV12-5 & 0.013 & 0.001 & 0.014 & 0.001 & $1.67 \times 10^{-11}$ & $6.80 \times 10^{-14}$ & 11.2 & 8.0 & 0.9 & 165 & 110 & 1 & 0.75 & 10.6 & 1.2 & $\mathrm{Y}$ & 5.2 & 2.4 & 6.7 & 3.4 \\
\hline $4-1$ & 1 & 0 & 0 & 0.007 & & 2.68 & & & 0 . & 160 & 115 & 1 & 0.76 & 4.6 & 0. & Y & & & & \\
\hline AV4-2 & 0.042 & 0.003 & 0.049 & & $2.23 \times 10^{-11}$ & $1.02 \times 10^{-13}$ & 9.6 & 3.1 & 0.3 & 260 & 185 & 2 & 0.84 & 3.8 & 0.4 & Y & & & & \\
\hline AV4-3 & 0.054 & 0.004 & 0.054 & 0.003 & $2.01 \times 10^{-11}$ & $9.23 \times 10^{-14}$ & 8.7 & 2.5 & 0.2 & 235 & 155 & 2 & 0.81 & 3.1 & 0.3 & Y & & & & \\
\hline AV4-4 & 0.024 & 0.002 & 0.018 & 0.001 & $7.47 \times 10^{-12}$ & $3.46 \times 10^{-14}$ & 9.0 & 2.6 & 0.2 & 200 & 160 & 2 & 0.80 & 3.2 & 0.3 & Y & & & & \\
\hline AV4-5 & 0.031 & 0.002 & 0.030 & 0.002 & $1.74 \times 10^{-11}$ & $8.05 \times 10^{-14}$ & 9.2 & 3.9 & 0.4 & 275 & 175 & 1 & 0.84 & 4.6 & 0.4 & $\mathrm{Y}$ & 3.1 & 0.5 & 3.9 & 0.7 \\
\hline $6-1$ & 094 & 0.006 & 0.039 & 0.002 & -11 & $1.54 \times 10^{-13}$ & 9.0 & 4.6 & 0.4 & 200 & 120 & 1 & 0.77 & 5.9 & 0.5 & $Y$ & & & & \\
\hline AV6-2 & 0.044 & 0.003 & 0.039 & 0.002 & & $7.22 \times 10^{-14}$ & 9.1 & 2.6 & 0.2 & 205 & 165 & 2 & 0.81 & 3.3 & 0.3 & Y & & & & \\
\hline AV6-3 & 0.055 & 0.004 & 0.045 & 0.003 & $4.10 \times 10^{-11}$ & $1.87 \times 10^{-13}$ & 9.6 & 5.8 & 0.6 & 230 & 150 & 2 & 0.80 & 7.3 & 0.7 & Y & 4.3 & 1.3 & 5.4 & 1.7 \\
\hline & 0 & & & & $66 \times 10^{-12}$ & $4.43 \times 10^{-14}$ & 9.7 & & 0 & 1 & 175 & 0 & 0 & 3.1 & 0.3 & $Y$ & & & & \\
\hline AV13-2 & 0.002 & 0.000 & 0.001 & 0.000 & $2.52 \times 10^{-13}$ & $1.16 \times 10^{-15}$ & 23.1 & 1.1 & 0.2 & 250 & 105 & 0 & 0.76 & 1.4 & 0.3 & $\mathrm{~B}, \mathrm{C}$ & & & & \\
\hline AV13-3 & 0.028 & 0.002 & 0.010 & 0.001 & $2.86 \times 10^{-11}$ & $8.58 \times 10^{-14}$ & 8.9 & 14.5 & 1.3 & 240 & 165 & 0 & 0.83 & 17.4 & 1.6 & A, C & & & & \\
\hline AV13-4 & 0.129 & 0.008 & 0.068 & 0.004 & $3.09 \times 10^{-11}$ & $1.41 \times 10^{-13}$ & 8.9 & 2.6 & 0.2 & 260 & 85 & 2 & 0.69 & 3.7 & 0.3 & Y & 2.6 & 0.2 & 3.4 & 0.3 \\
\hline
\end{tabular}

${ }^{\mathrm{a}} \mathrm{The}{ }^{232} \mathrm{Th},{ }^{238} \mathrm{U}$, mass of Th and $\mathrm{U}$ in the grain (ng) and corresponding $1 \sigma$ analytical error $(\mathrm{ng}) ;{ }^{4} \mathrm{He}$, volume of He extracted (cm $\left.{ }^{3}\right)$, in standard laboratory conditions and corresponding $1 \sigma$ analytical error $\left(\mathrm{cm}^{3}\right)$; TA error, total analytical error (\%) calculated from the $1 \sigma$ analytical errors on ${ }^{232} \mathrm{Th}$, ${ }^{238} \mathrm{U}$ and ${ }^{4} \mathrm{He}$; Raw age: grain age before applying the $\mathrm{F}_{\mathrm{t}}$ alpha-ejection correction factor (Ma); $1 \sigma$ age err: analytical error on raw age (Ma); $\mathrm{L}$ and $\mathrm{W}$, length and width of crystal $(\mu \mathrm{m})$; Tr, number of intact crystal terminations; $\mathrm{F}_{\mathrm{t}}$ : alpha correction factor [Farley, 2002]; Corr age: grain age after dividing the raw age by the $\mathrm{F}_{\mathrm{t}}$ alpha ejection correction factor (Ma); $1 \sigma$ age error, analytical error on corrected age (Ma); Use, use of a replicate age in the calculation of uncertainty-weighted age (Y), or reason for discarding the replicate before uncertainty-weighted age calculation. These reasons include A, He extraction at second heating amounting to more than $5 \%$ of the extraction at first heating (suggesting the presence of He-rich inclusion); B, blank level He extraction at first heating; C, ICP-MS isotopic counts per second smaller than our limit of quantification (10 times the number of counts per second measured with ultrapure $5 \mathrm{M} \mathrm{HNO}_{3}$ blank); $\mathrm{D}$, a single replicate age is close to zero (suggesting the presence of a U-rich inclusion), or in samples with more than three valid replicates: $\mathrm{a} \pm 2 \sigma$ confidence interval around the raw age is isolated from every other valid replicate; WR age, analytical uncertainty-weighted raw age (Ma); WR error, weighted $1 \sigma$ standard deviation or average $1 \sigma$ analytical error, whichever is highest, on weighted raw age (Ma); WC age, analytical uncertainty-weighted-corrected age (Ma); WC error, weighted $1 \sigma$ standard deviation or average $1 \sigma$ analytical error, whichever highest, on weightedcorrected age (Ma). Samples are ranked in decreasing elevation order. 

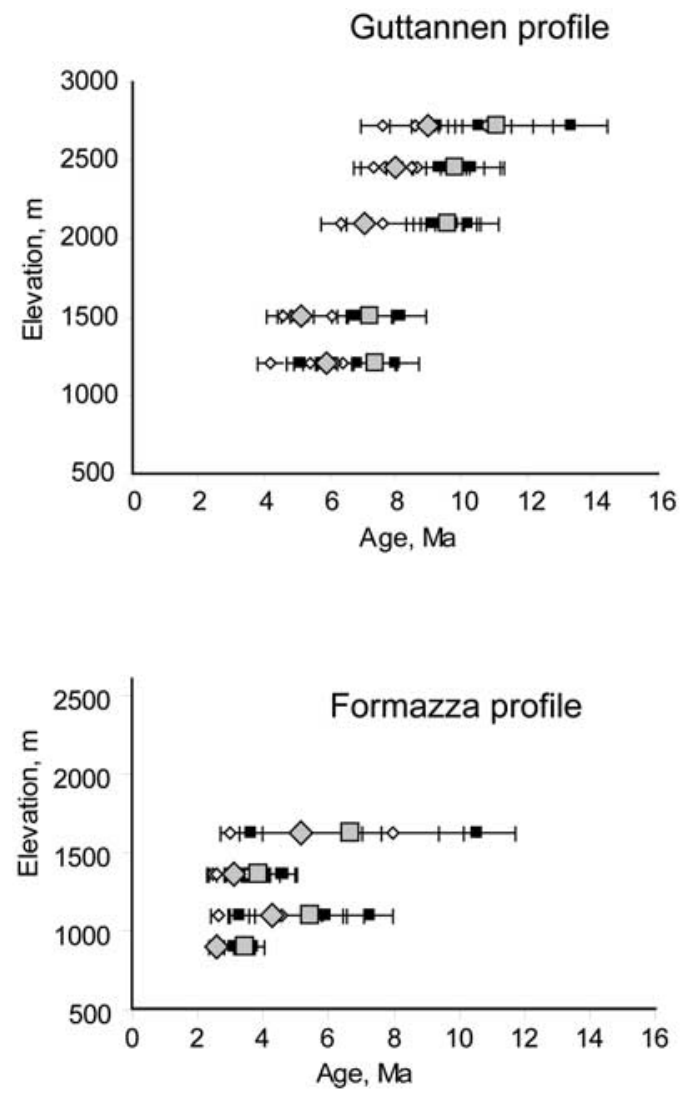

- AHe single grain raw age $\diamond$ Weighted AHe raw age

- AHe single grain corrected age $\square$ Weighted AHe corrected age

Figure 5. Spread of single-grain uncorrected (white diamonds) and corrected (black squares) AHe ages with $1 \sigma$ analytical uncertainty, compared to weighted-average AHe ages (weighted according to $1 \sigma$ analytical uncertainty; gray diamonds and squares, respectively, with error bars as explained in Table 3) for the Guttannen and Formazza elevation profiles.

this study. The emission distance was set at $20 \mu \mathrm{m}$, the activation energy at $8.65 \mathrm{~kJ} / \mathrm{mol}$ and $\mathrm{D}_{0}$ at $1807.8 \mathrm{~cm}^{2} / \mathrm{s}$.

[24] In the conditions tested, the apparent age of zoned apatites varies between $-30.8 \%$ and $+49.7 \%$ of the age calculated for unzoned apatites (Table 4 and Figure 9). The model confirms that apatites with a strong internal zoning of $\mathrm{U}$ and Th (cases D and E) may have apparent ages that are much older than under the assumption of no zoning, and therefore do not require application of an alpha ejection correction. The dependency of age on U-Th zoning might explain the overlap between AFT and AHe ages exposed in Figure 7.

\section{Qualitative Interpretation of Age-Elevation Relationships}

[25] All AFT and AHe ages obtained on the Guttannen and the Formazza elevation profiles are plotted in Figure 7, including AFT samples with multiple grain age populations. The comparison between AFT central ages, raw and alphaejection-corrected AHe ages in the Guttannen elevation profile (Figure 7) shows that uncorrected $\mathrm{AHe}$ ages are generally slightly younger than AFT ages, but the corrected AHe ages are older. The similarity of the AFT and AHe ages and the steepness of the age-elevation relationships in the Guttanen profile (Figure 7) suggest that rapid cooling, and therefore exhumation, occurred around 9-7 Ma.

[26] On the Guttannen profile, the elevation of the zero age intersect of the AFT age-elevation regression line lies $\sim 6000 \mathrm{~m}$ below sea level (Figure 4), i.e., at least $7150 \mathrm{~m}$ below the valley bottom. Assuming a $20-30^{\circ} \mathrm{C} / \mathrm{km}$ geothermal gradient [Kohl, 1999], the temperature at this depth is 140 to $210^{\circ} \mathrm{C}$. This is clearly above the closure temperature for the AFT system, requiring that the cooling rate of the Aar Massif has slowed since $\sim 7 \mathrm{Ma}$, which is the approximate AFT age of the lowest samples displaying a

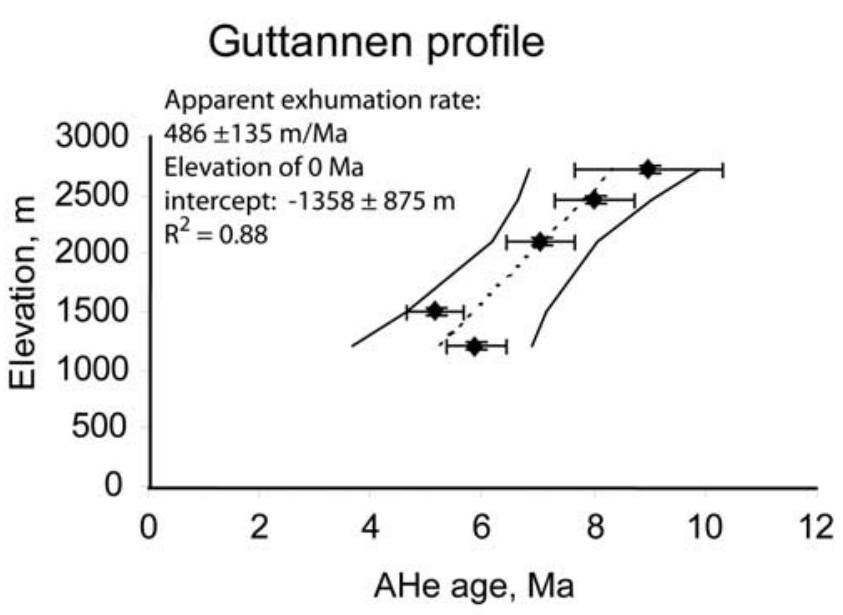

\section{Formazza profile}

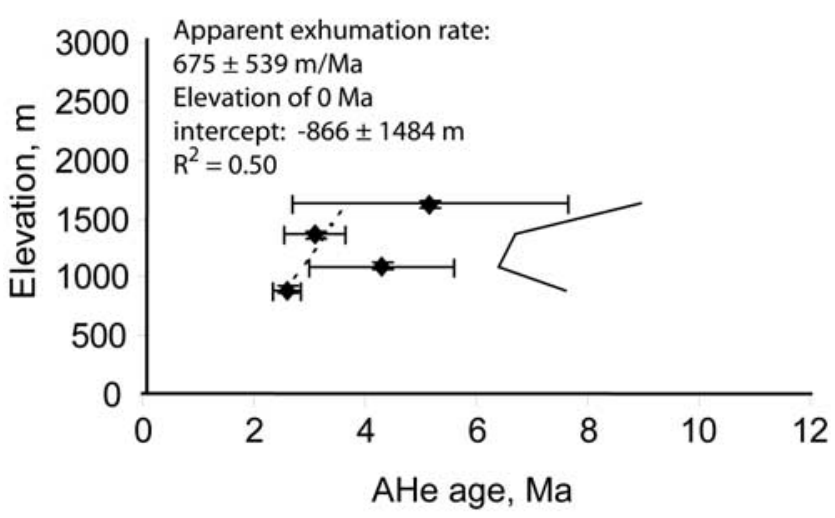

Figure 6. AHe age-elevation profiles and weighted regression relationship (dashed line, regression line; bold lines, 95\% confidence interval) for the Guttannen and the Formazza areas. Weighted-average-uncorrected AHe ages were used, with error bars as explained in Table 3. 

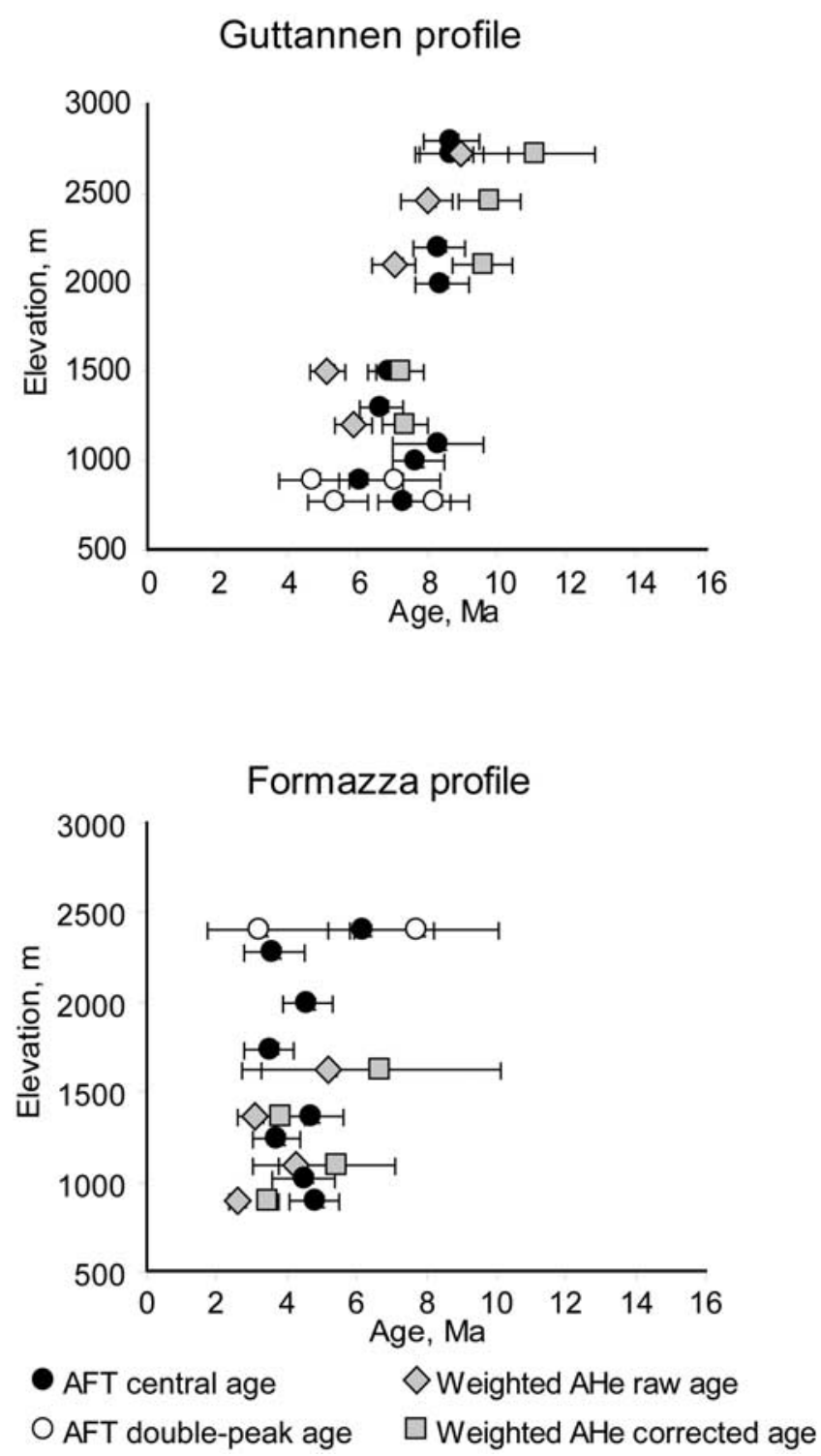

Figure 7. Comparison of AFT ages (circles, $1 \sigma$ error bars) with uncorrected (diamonds) and alpha-ejection-corrected (squares) $1 \sigma$ analytical uncertainty-weighted average AHe ages (with error bars as explained in Table 3), obtained in the Guttannen and the Formazza elevation profiles. White circles are used in addition to the black symbols showing central age, in samples where single-grain AFT ages are dispersed and can be characterized as belonging to several age populations, each grouping at least $30 \%$ of dated grains.

single age population in the profile. The presence of two samples with multiple age populations at the base of the profile (open circles in Figure 7) is consistent with this interpretation as they may result from a slower passage of the partial annealing zone after $\sim 7 \mathrm{Ma}$, dispersing the ages of individual grains.

[27] The AHe age-elevation relationship shows a zero age intercept at $\sim 1350 \mathrm{~m}$ below sea level (Figure 6), i.e., at least $2350 \mathrm{~m}$ below the valley bottom, where we expect temper-

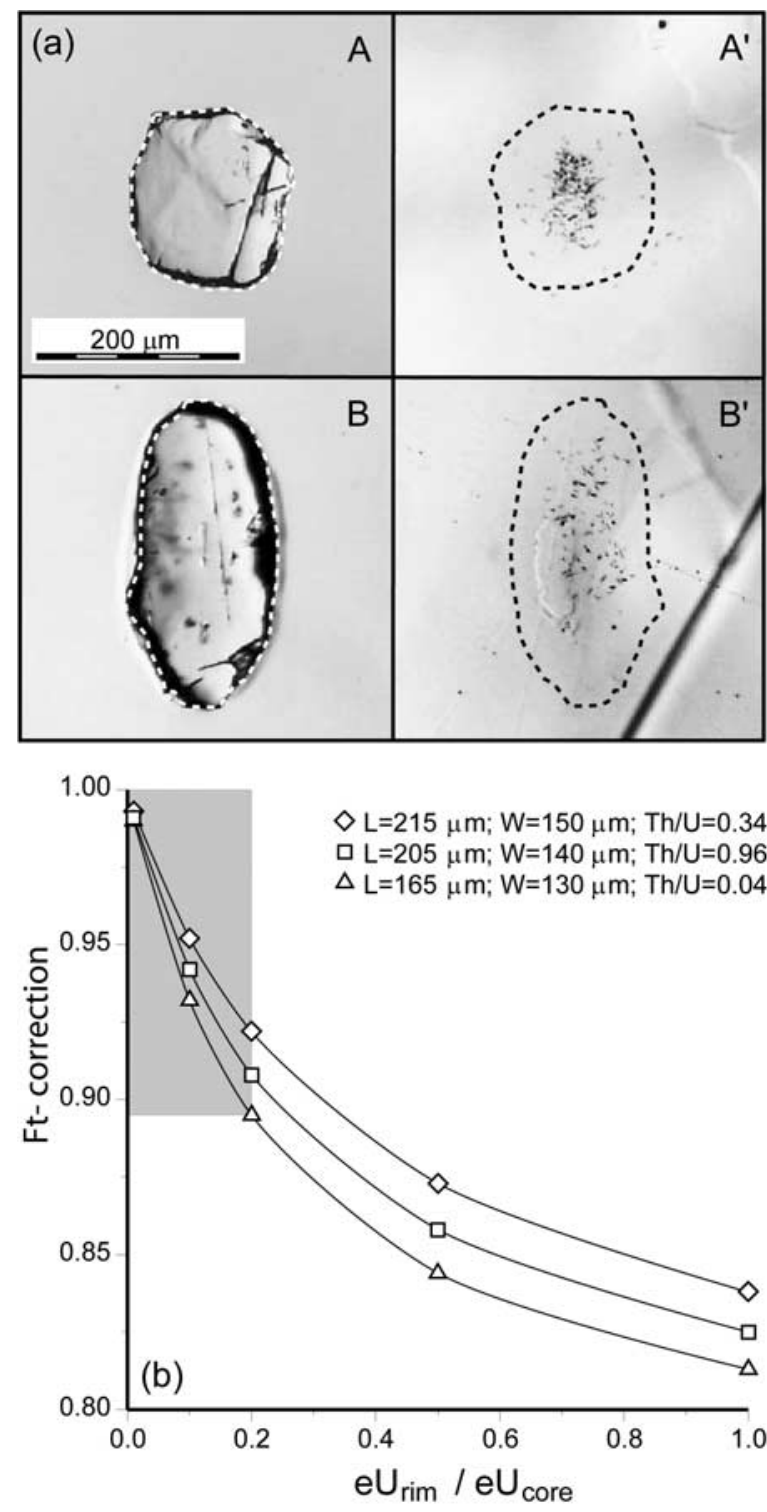

Figure 8. (a) Two examples of internal $U$ zoning in apatites dated in this study, as recorded by the distribution of induced track in mica detectors used for AFT dating (A and $\mathrm{A}^{\prime}$, sample AV4; $\mathrm{B}$ and $\mathrm{B}^{\prime}$, sample AV2). The area covered by induced fission tracks in the mica detector $\left(\mathrm{A}^{\prime}, \mathrm{B}^{\prime}\right)$ is clearly smaller than the polished area of the corresponding crystals (A, B). Dashed lines indicate the grain contour. In both cases, the outer U-poor layer is $30-40 \mu \mathrm{m}$ thick. (b) Predicted Ft correction factor from a Monte Carlo model of He ejection [Gautheron et al., 2008] for different crystal sizes (length $\mathrm{L}$, width $\mathrm{W}$ ), $\mathrm{Th} / \mathrm{U}$ ratios (provided in key) and $\mathrm{U}$ depletion in a $30 \mu \mathrm{m}$ wide $\mathrm{rim}\left(\mathrm{eU}_{\text {rim }} / \mathrm{eU}_{\text {core, }}\right.$, with $\mathrm{eU}$ the effective uranium concentration as in the work by Shuster et al. [2006]). Grain sizes, $\mathrm{Th} / \mathrm{U}$ ratios, and rim widths are characteristic of samples in this study. Shaded box corresponds to inferred range of Ft corrections applicable to our samples (compare to "standard" Ft correction for unzoned apatite; $\left.\mathrm{eU}_{\text {rim }} / \mathrm{eU}_{\text {core }}=1\right)$. 
atures of $45-70^{\circ} \mathrm{C}$. This is undistinguishable from the $\mathrm{He}$ closure temperature in rapidly cooling apatites and therefore does not require a change in exhumation rate since $\sim 9 \mathrm{Ma}$ (the highest AHe age in the elevation profile), in contrast to the AFT data above. There is a contradiction between the two exhumation scenarios interpreted from the depth of the zero age intersects of the AFT and AHe age-elevation
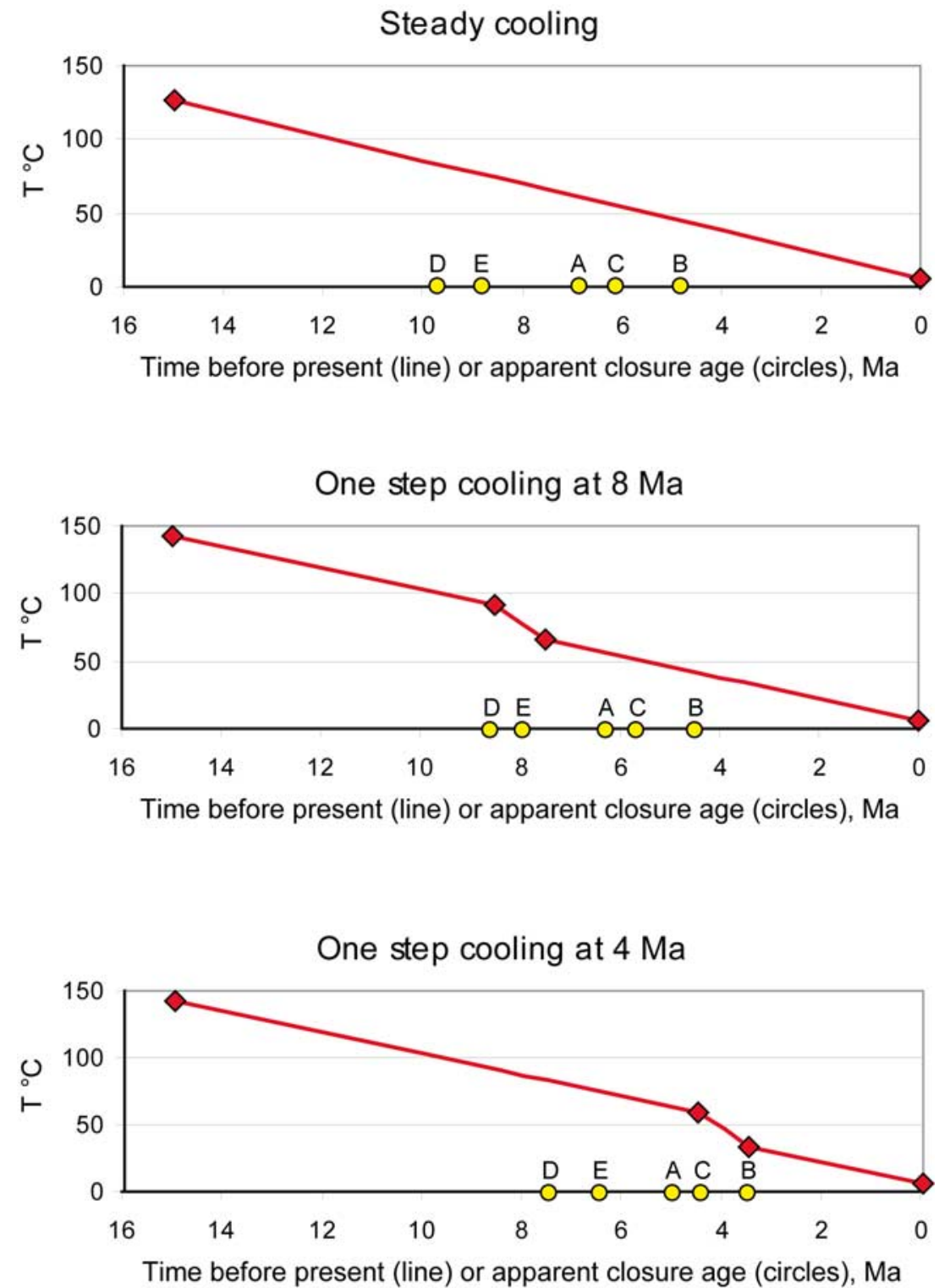

Two steps cooling at $8 \& 4 \mathrm{Ma}$

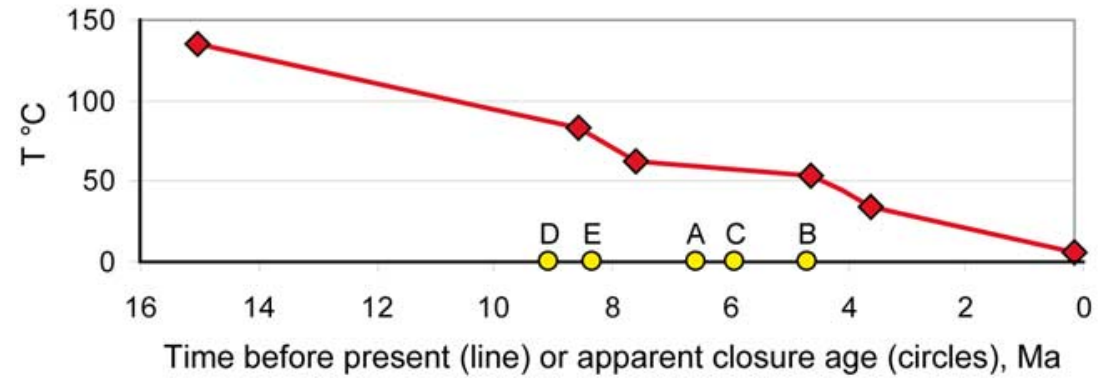

Figure 9 
Table 4. Comparison Between Decomp Modeled AHe Ages for Different Cooling Scenarios ${ }^{\mathrm{a}}$

\begin{tabular}{lccccc}
\hline & A & B (\% A) & C (\% A) & D (\% A) & E (\% A) \\
\hline Steady cooling rate & 6.8 & $4.8(-29.8)$ & $6.1(-10.6)$ & $9.7(+41.7)$ & $8.8(+28.4)$ \\
Faster cooling at 8 Ma & 6.3 & $4.5(-28.4)$ & $5.7(-9.7)$ & $8.6(+37.1)$ & $8.0(+27.1)$ \\
Faster cooling at 4 Ma & 5.0 & $3.4(-30.8)$ & $4.4(-11.7)$ & $7.4(+49.7)$ & $6.4(+29.3)$ \\
Faster cooling at 8 and 4 Ma & 6.5 & $4.7(-28.7)$ & $5.9(-9.9)$ & $9.0(+38.2)$ & $8.3(+27.4)$ \\
\hline
\end{tabular}

${ }^{\mathrm{a}}$ Each period of faster cooling lasts for $1 \mathrm{Ma}$, centered on the age indicated (see Figure 9). A (Ma): apparent age for nonzoned apatites (Ma), B and C, apparent age and age difference (in \% of age A) in two cases of external zoning; D and E, apparent age and age difference (in \% of A) in two cases of internal zoning. Details on B-E zoning are given in Figure 9 caption.

regression lines, which can tentatively be explained by the relatively high age uncertainties.

[28] On the Formazza profile, the low number and the relative dispersion of $\mathrm{AHe}$ data do not enable us to use the AER with confidence (Figure 6). The uncorrected AHe ages are generally in the same range as AFT ages, but corrected AHe ages are slightly older (Figure 7). The observation of a sample with two AFT age populations at the top of the profile may result from a relatively slow passage of the partial annealing zone prior to $\sim 5 \mathrm{Ma}$, having caused individual apatite ages to disperse. The overlapping AFT and AHe ages in Formazza, together with the steep to negative AER and the presence of a sample with dispersed individual grains age at the top of the profile might result from a period of fast exhumation around 5-4 Ma, following a period of slower passage through the AFT partial annealing zone prior to $\sim 5 \mathrm{Ma}$.

[29] The combination of observations in the Guttannen and the Formazza profiles suggests a common period of slow exhumation centered on 7-5 Ma, with a period of rapid exhumation before (recorded in the Guttannen profile) and after (recorded in the Formazza profile). Without higher-temperature thermochronometer data (such as zircon (U-Th)/He), we cannot assess the evidence for a similar period of rapid exhumation prior to $\sim 7 \mathrm{Ma}$ in Formazza. Given the generally younger cooling ages in the Italian profile, it is clear that the average exhumation rate since $6 \mathrm{Ma}$ has been higher there than in the Swiss profile (Figure 3). Our qualitative analysis of AFT and AHe data on two elevation profiles along a N-S transect linking the Aar Massif to the Lepontine Dome thus lead us to propose the following scenario for late Neogene exhumation: a period of fast exhumation (9-7 Ma) was followed by 2 Ma of slow cooling (7-5 Ma). Subsequently, exhumation increased again (5-4 Ma), but more intensely on the southern flank of the orogen. This latest observation provides some support for the hypothesis of acceleration in alpine exhumation at
5 Ma [e.g., Kuhlemann, 2000; Cederbom et al., 2004; Willett et al., 2006; Vernon et al., 2008].

[30] If we assume that the AFT age at the top of the Formazza profile ( $\sim 2400 \mathrm{~m}$ elevation) and the two AFT ages at the bottom of the Guttannen profile $(\sim 850 \mathrm{~m}$ elevation) remained for a longer time than other samples in the partial annealing zone between 7 and $5 \mathrm{Ma}$ (Figure 7), and if the elevation of the partial annealing zone was comparable in both areas at the time of closure, then we infer a minimal additional exhumation of circa $1550 \mathrm{~m}$ during the last $5 \mathrm{Ma}$ in Formazza compared to Guttannen. This is a minimum estimate, as it does not integrate the width of the partial annealing zone between its base (corresponding to the samples in Formazza) and its summit (corresponding to the samples in Guttannen).

\section{Prediction and Comparison of Exhumation Histories Using Pecube}

[31] In previous studies, age-elevation profiles have often been directly interpreted in terms of exhumation rates [Michalski and Soom, 1990; Lihou et al., 1995; Rahn et al., 1997] even though the slopes of age-elevation relationships might be overestimated (see section 3.1).

[32] The program Pecube solves for the thermal structure of the crust and the cooling history of rocks that are currently at the surface for arbitrary exhumation and relief histories. The version used here is based on the version of Braun and Robert [2005], which includes isostatic response to relief change, calculates apatite fission track and (U-Th)/ He ages and compares these with input data. AFT ages are calculated using the Green et al. [1989] annealing model but with model parameters as recalculated by Stephenson et al. [2006]. (U-Th)/He ages are calculated for a spherical diffusion model within a $100 \mu \mathrm{m}$ diameter and diffusion parameters from Farley [2000]. Braun [2002, 2003] provides detailed explanations of the thermal calculations.

Figure 9. Effect of $U$ and Th zonation on calculated AHe ages using Decomp, for four different cooling scenarios. In each case, total cooling is $\sim 130^{\circ} \mathrm{C}$ in the last $15 \mathrm{Ma}$, with times of cooling rate change underlined by a diamond. Five different cases of $\mathrm{U}$ and $\mathrm{Th}$ zonation are tested for each cooling history. A, unzoned apatite of $75 \mu$ m radius; B, externally zoned apatite with $\mathrm{U}$ and Th concentrated in the outer $15 \mu \mathrm{m}$; $\mathrm{C}$, externally zoned apatite with $\mathrm{U}$ and Th concentrated in the outer $30 \mu \mathrm{m}$; D, internally zoned apatite with $\mathrm{U}$ and Th concentrated in the inner $30 \mu \mathrm{m}$; E, internally zoned apatite with $\mathrm{U}$ and Th concentrated in the inner $60 \mu \mathrm{m}$. The circles represent predicted AHe ages for these five cases of zonation; their spread underlines the large impact of zonation on apparent AHe age (see text for details on the method). 
Table 5. Values of Fixed Crustal, Thermal, and Flexural Parameters Used in Pecube Runs

\begin{tabular}{|c|c|c|}
\hline & Value & Reference $^{\mathrm{a}}$ \\
\hline \multicolumn{3}{|l|}{ Parameters for thermal calculation } \\
\hline Model crustal thickness C & $50 \mathrm{~km}$ & Stampfli et al. $[1998]$ \\
\hline Number of nodes in the vertical (z) direction $\mathrm{nz}$ & 21 & \\
\hline Thermal diffusivity $\kappa$ & $25 \mathrm{~km}^{2} \mathrm{Ma}^{-1}$ & Braun and Robert [2005] \\
\hline Temperature at the base of the model $\mathrm{T}_{\max }$ & $650^{\circ} \mathrm{C}$ & Bousquet et al. [1997] \\
\hline Temperature at sea level $\mathrm{T}_{0}$ & $15^{\circ} \mathrm{C}$ & \\
\hline Atmospheric lapse rate $G$ & $6^{\circ} \mathrm{C} \mathrm{km}^{-1}$ & \\
\hline Crustal heat production $\mathrm{H}$ & $8^{\circ} \mathrm{C} \mathrm{Ma}^{-1}$ & Braun and Robert [2005] \\
\hline Erosional response time $\tau$ & $1000 \mathrm{Ma}$ & \\
\hline \multicolumn{3}{|l|}{ Parameters for plate flexure } \\
\hline Crustal density $\rho_{\mathrm{c}}$ & $2700 \mathrm{~kg} \mathrm{~m}^{-3}$ & \\
\hline Sublithospheric mantle density $\rho_{\mathrm{m}}$ & $3200 \mathrm{~kg} \mathrm{~m}^{-3}$ & \\
\hline Young's modulus Y & $10^{+11} \mathrm{~Pa}$ & \\
\hline Poisson ratio $\nu$ & 0.25 & \\
\hline Equivalent elastic thickness $\mathrm{Te}$ & $20 \mathrm{~km}$ & Burov and Diament [1996] \\
\hline
\end{tabular}

${ }^{\mathrm{a}}$ References are given for parameter values where appropriate.

[33] As Pecube can only be used over limited areas, where the geothermal gradient, exhumation history and thermal properties of the crust are assumed homogeneous, we limited our models to two $37 \times 38 \mathrm{~km}$ regions, centered on the Guttannen and the Formazza profiles (locations indicated by boxes in Figure 1), using a $1 \mathrm{~km}$ resolution resampled version of the digital elevation model available from the CGIAR-CSI SRTM $90 \mathrm{~m}$ database (http://srtm. csi.cgiar.org). We tested more than 120 different exhumation and relief change scenarios in each area, fixing the thermal parameters of the crust as well as the values of flexural parameters used to include the isostatic response to relief change, as detailed in Table 5. We calculated AFT and AHe ages for each surface grid node from the predicted cooling histories and then calculated the cumulated misfit $(\mu)$ between observed and predicted ages in order to assess the likelihood of each set of parameters tested (Figure 10):

$$
\mu=\sqrt{\sum_{i=1}^{n}\left(\frac{\mathrm{age}_{\mathrm{obs}}-\mathrm{age}_{\mathrm{pred}}}{\sigma_{\mathrm{age}_{\mathrm{obs}}}}\right)^{2}},
$$

where age $\mathrm{obs}_{\mathrm{os}}$ and age $\mathrm{e}_{\mathrm{pred}}$ are the observed and predicted ages, respectively, and $\sigma_{\text {age }_{\text {obs }}}$ is the uncertainty on the observed age. For the misfit calculation we used either central AFT ages or the main age peak component in cases where it included more than $70 \%$ of the grains counted (see Table 2); otherwise the age was not used. The AHe ages used in the model were not corrected for alpha ejection, due to presumed $\mathrm{U}$ and Th zoning susceptible to cause overestimation of the correction factor.

[34] We performed Pecube runs for four types of exhumation scenarios characterized by either a constant exhu- mation rate, one or two temporary exhumation pulses, or a single step of exhumation increase (Figures 11-14). Every model was run over a period long enough to exhume $6000 \mathrm{~m}$ of material, to ensure that the material exposed at the surface at the final stage was located deeper than the AFT partial annealing zone at the onset of the model run. Relief evolution is defined by a factor $\beta$ defined for each time step, such that at that time step, the elevation difference between any pixel in the model and the maximum elevation equals $\beta$ times the present-day value. We tested scenarios in which relief increased $(\beta<1)$ or decreased $(\beta>1)$ homogeneously or stepwise through time, as well constant relief scenarios $(\beta=1)$.

[35] Our first set of runs tested different rates of constant exhumation and either steady relief or continuously increasing (initial $\beta=0.4$ ) or decreasing (initial $\beta=1.6$ ) relief (Figure 11). In the Formazza area, the best fitting scenario (cumulated misfit $\mu=4.4$, case B in Figures 11 and 15) is obtained for $750 \mathrm{~m} / \mathrm{Ma}$ (insensitive to relief change), and in the Guttannen area (cumulated misfit: $\mu=7.4$, case A in Figures 11 and 15) for $400 \mathrm{~m} / \mathrm{Ma}$ (with increasing relief corresponding to valley deepening). However, some of the other scenarios tested provided slightly better misfit values in Guttannen.

[36] We subsequently tested models including a single 2-Ma exhumation pulse, centered at either 8 or at $4 \mathrm{Ma}$ (see color code on Figure 12). We tested different scenarios of exhumation rate variation (i-1, moderate; $i-2$, strong; i-3, extreme) and either steady relief, continuous relief reduction from $\beta=1.5$, continuous relief increase from $\beta=0.5$, or a temporary increase to $\beta=1.5$ during exhumation pulses. In Guttannen, best fits are obtained for a pulse in exhumation rate centered at $4 \mathrm{Ma}$, with steadily or temporarily increasing

Figure 10. Comparison between two AFT age Pecube predictions in the Formazza area, with either (a) a high total misfit value of 13.3 or (b) a low misfit value of 4.2. The two scenarios have constant exhumation rates of 500 and $750 \mathrm{~m} / \mathrm{Ma}$, respectively; both have constant relief throughout the run. The color scale on the maps corresponds to Pecube-predicted ages on $1 \times 1 \mathrm{~km}$ pixels, while the dots show measured AFT ages, with the same color code. The age-elevation insets show the superposition of the measured AFT ages (black squares with $1 \sigma$ error bars) and the ages predicted at the same locations by the Pecube model (open squares). Note that all samples within the Formazza area are plotted here; not only those from the elevation profile presented in Figure 4. 

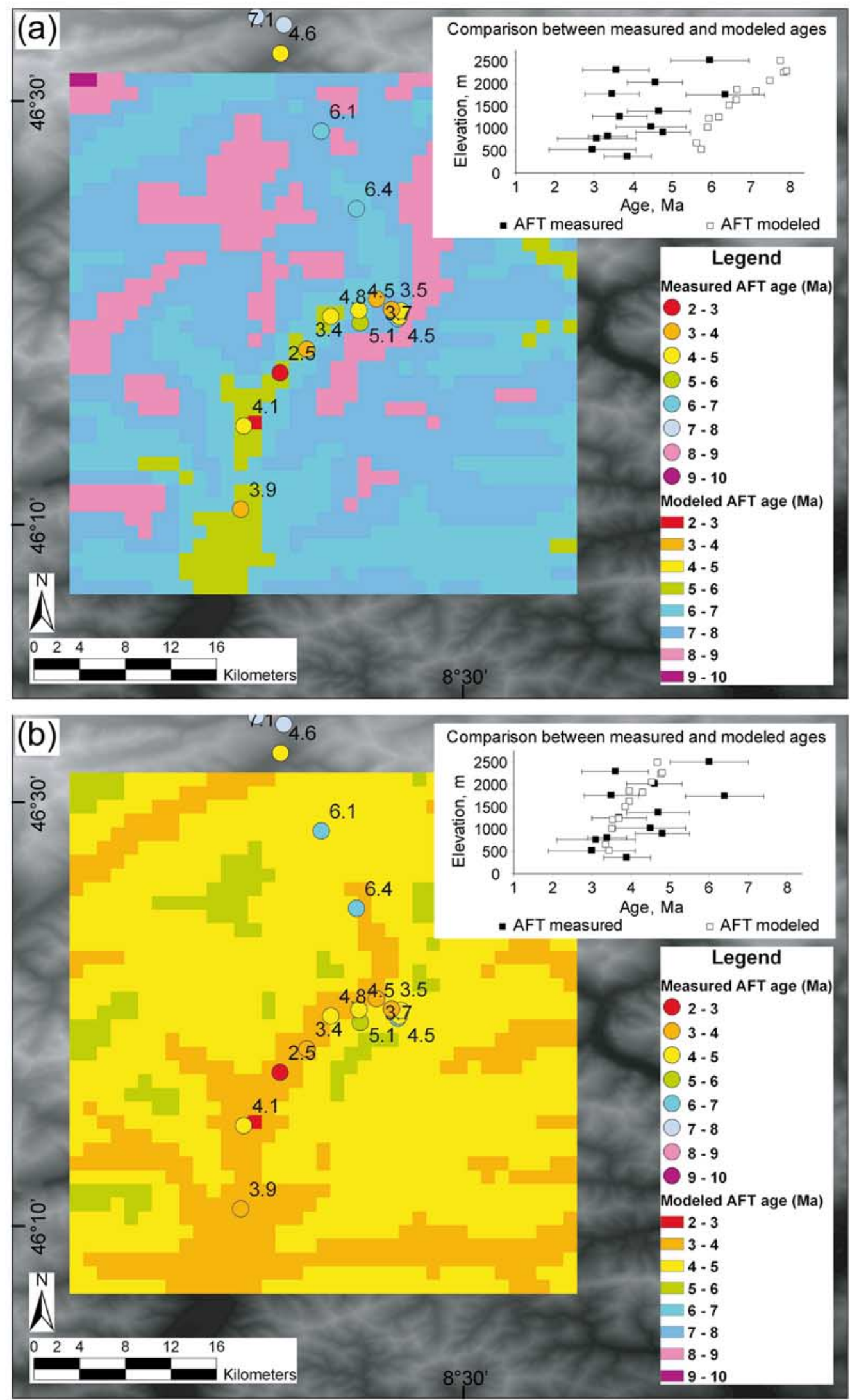

Figure 10 

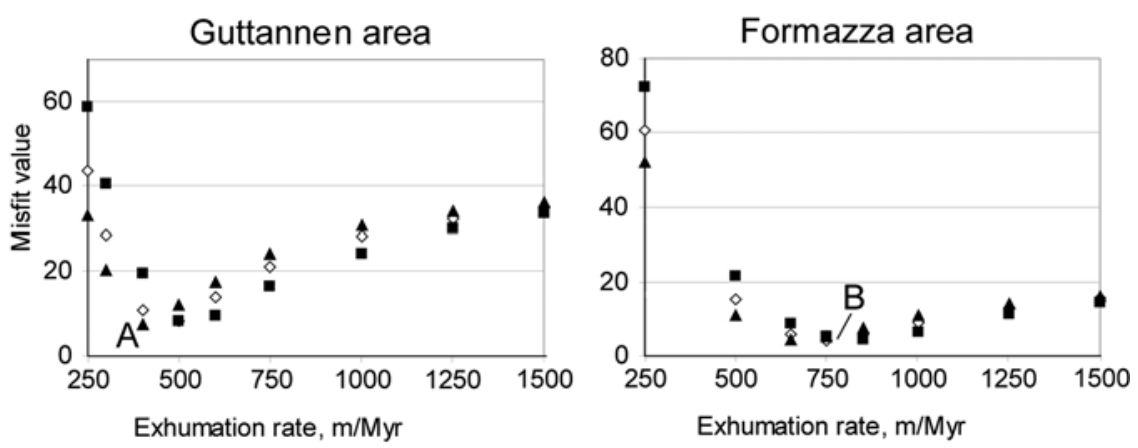

Figure 11. Cumulated misfit between predicted and measured AFT and AHe ages in the Guttannen and the Formazza study areas for different values of steady exhumation rate (plotted on $x$ axis) and relief variation. Diamonds, steady relief; squares, relief reduction from $\beta=1.6$ to 1 ; triangles, relief increase from $\beta=0.4$ to 1 . A $(\mu=7.4)$ and $\mathrm{B}(\mu=4.4)$ refer to cases $\mathrm{A}$ and $\mathrm{B}$ in Figure 15. See text for details on the method.

relief. The scenarios with an extreme variation in exhumation rate (100 to $1000 \mathrm{~m} / \mathrm{Ma}$ during the pulses) illustrate the important role played by relief change when the background exhumation rate is very low $(100 \mathrm{~m} / \mathrm{Ma})$. In Formazza, we observe a broadly similar pattern although the scarcity of AFT and AHe ages older than $6 \mathrm{Ma}$ in this profile does not allow us to accurately test models involving an exhumation pulse centered at $8 \mathrm{Ma}$. In both areas, relatively high misfit values ( $\mu=8.4$ and 16.2, respectively, for the best fit) led us to discard scenarios involving a single exhumation pulse.

[37] Third, we tested models that included two exhumation pulses, both lasting for $2 \mathrm{Ma}$ and centered at 8 and (a)

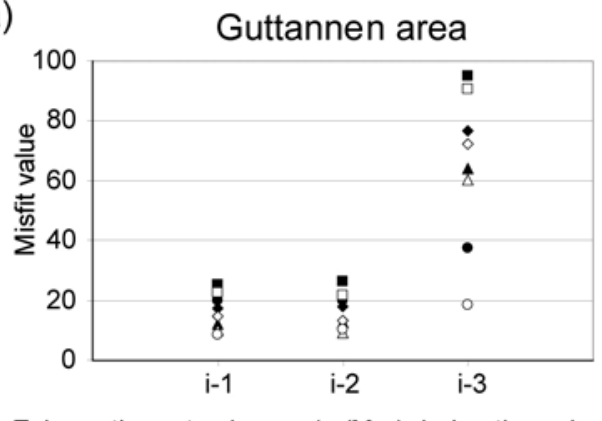

Exhumation rate change (m/Myr) during the pulse: $\mathrm{i}-1$ )

(b)

Exhumation scenarios for black symbols

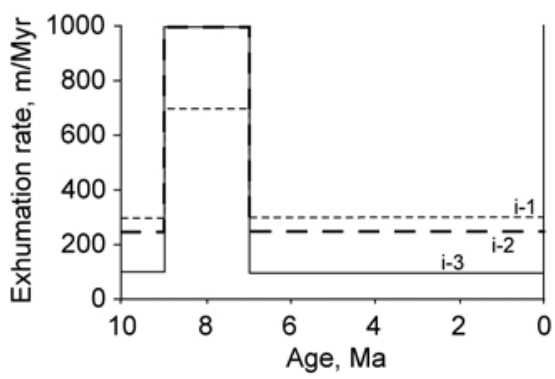

Formazza area

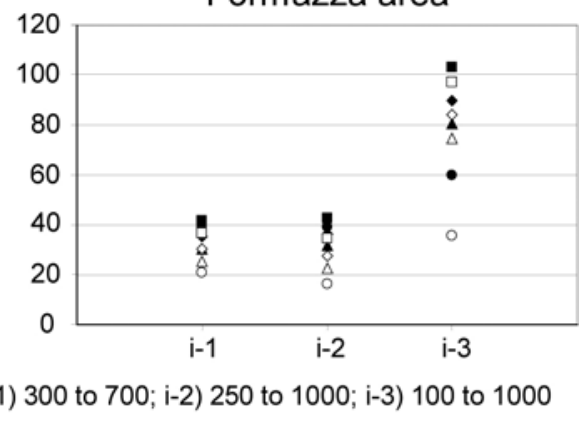

Exhumation scenarios for white symbols

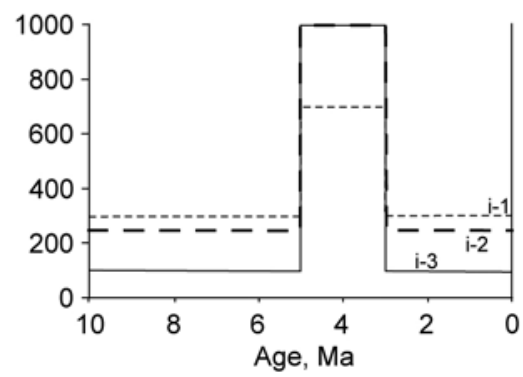

Figure 12. (a) Cumulated misfit between predicted and measured AFT and AHe ages in the Guttannen and the Formazza study areas, for different intensities (i-1, i-2, i-3) of 2-Ma-long exhumation pulses centered at either $8 \mathrm{Ma}$ (black) or $4 \mathrm{Ma}$ (white) and a choice of relief variation. Diamonds, steady relief; squares, relief reduction from $\beta=1.5$ to 1 ; triangles, relief increase from $\beta=0.5$ to 1 ; circles, temporary relief increase from $\beta=1$ to 1.5 during exhumation pulses. See text for further details on the method. (b) Illustration of the 6 different exhumation rate scenarios tested, centered at 8 or $4 \mathrm{Ma}$ and with i-1, i-2, or i-3 intensity variation as detailed in the legend. 
(a)

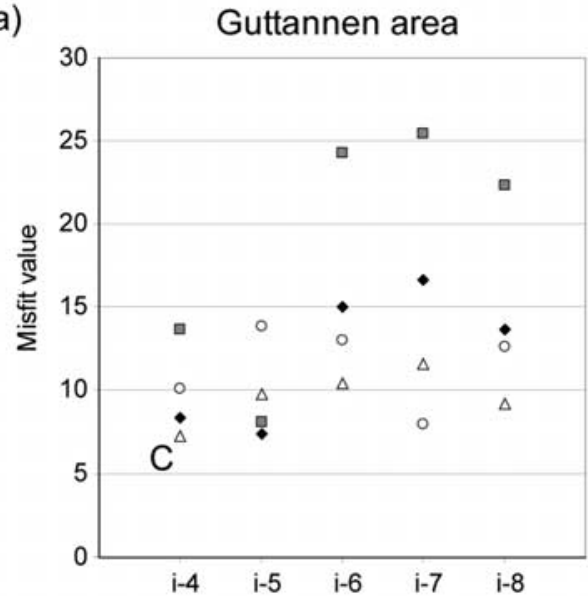

Formazza area

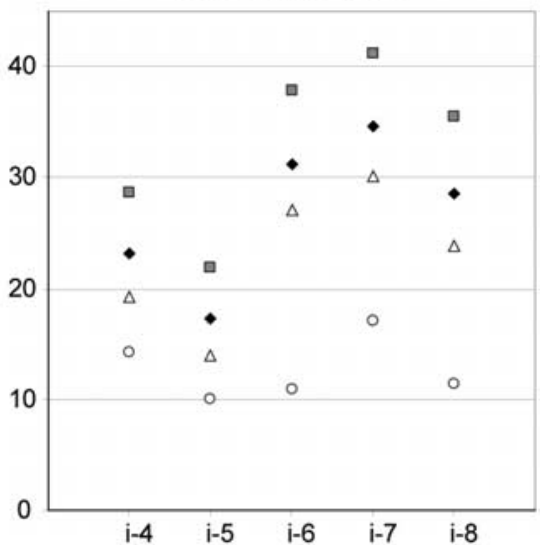

Exhumation rate change (m/Myr) during pulses: $\mathrm{i}-4) 300$ to 700 ; i-5) 250 to 1000 ; i-6) 100 to 1000 ; i-7) 200 to 1000 for the $8 \mathrm{Ma}$ pulse and 200 to 500 for the $4 \mathrm{Ma}$ pulse; i-8) 200 to 500 for the $8 \mathrm{Ma}$ pulse and 200 to 1000 for the $4 \mathrm{Ma}$ pulse

(b)
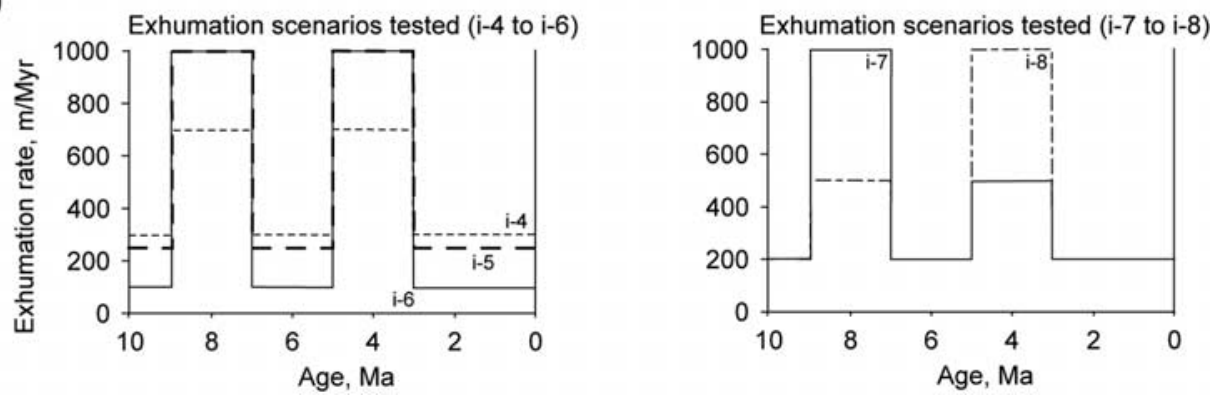

Figure 13. (a) Cumulated misfit between predicted and measured AFT and AHe ages in the Guttannen and the Formazza study areas for different intensities (i-4, i-5, i-6, i-7, i-8) of two 2-Ma-long exhumation pulses centered at 8 and $4 \mathrm{Ma}$ and a choice of relief variation. Diamonds, steady relief; squares, relief reduction from $\beta=1.5$ to 1 ; triangles, relief increase from $\beta=0.5$ to 1 ; circles, temporary relief increase from $\beta=1$ to 1.5 during exhumation pulses. See text for further details on the method. $\mathrm{C}(\mu=7.2)$ refers to case $\mathrm{C}$ in Figure 15. (b) Illustration of the five different exhumation rate scenarios tested, with i-4, i-5, i- 6 , i-7, or i- 8 intensity variation centered at 8 or 4 Ma as detailed in the legend.
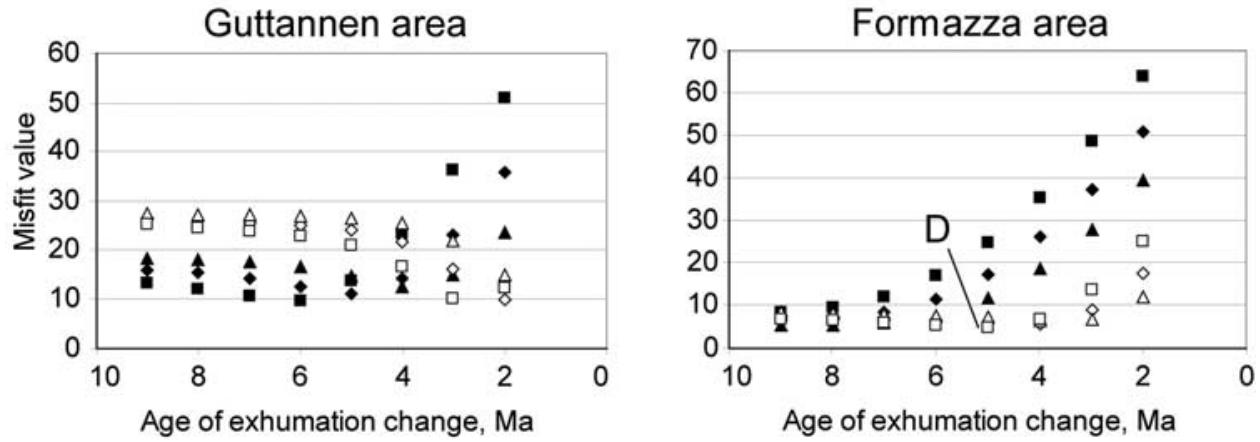

Figure 14. Cumulated misfit between predicted and measured AFT and AHe ages in the Guttannen and the Formazza study areas for different scenarios of single-step exhumation rate increase occurring at the age indicated on the $x$ axis, with different intensities $(200$ to $700 \mathrm{~m} / \mathrm{Ma}$ in black, or 300 to $1000 \mathrm{~m} / \mathrm{Ma}$ in white) and a choice of relief variation. Diamonds, steady relief; squares, relief reduction from $\beta=1.3$ to 1 ; triangles, relief increase from $\beta=0.7$ to 1 . See text for further details on the method. $\mathrm{D}(\mu=4.8)$ refers to case D in Figure 15. 

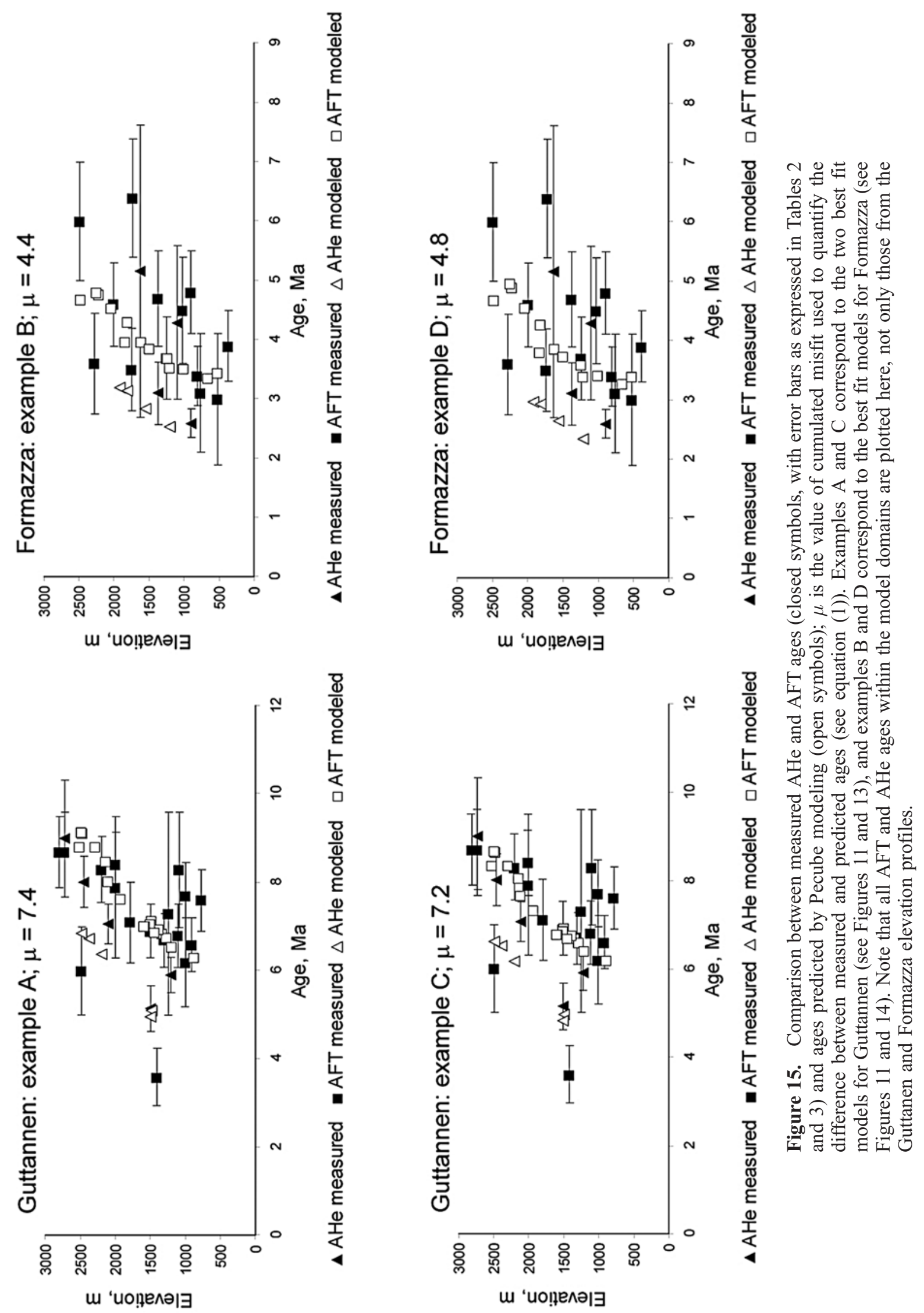
$4 \mathrm{Ma}$, respectively (Figure 13). The first three exhumation scenarios tested (i-4 to i-6) involve two exhumation pulses of equal importance, whereas the two last scenarios (i-7 and i-8) test exhumation pulses that differ in intensity. The relief conditions were either steady, continuously decreasing from $\beta=1.5$, continuously increasing from $\beta=0.5$, or increasing temporarily to $\beta=1.5$ during exhumation pulses. In Guttannen, the best fitting scenario (cumulated misfit $\mu=$ 7.2) is obtained for a moderate increase in exhumation rate (300 to $700 \mathrm{~m} / \mathrm{Ma}$ ) during two periods (9-7 and 5-3 Ma), in a context of increasing relief. However, another scenario with constant relief and a stronger contrast in exhumation rates (250 to $1000 \mathrm{~m} / \mathrm{Ma}$ ) yields an almost equally good misfit value $(\mu=7.4)$, underlining the low resolution we have to precisely quantify variations in exhumation rate. In contrast, relief change can have a strong effect, such that most scenarios involving relief decrease (squares) yield very high misfit values. The best fit scenario modeled in Guttannen (case $\mathrm{C}$ in Figures 13 and 15) constitutes a quantitative validation of the observations made qualitatively on AFT and AHe elevation profiles in Guttannen and Formazza (section 5 and Figure 7): an exhumation rate slower between 7 and $5 \mathrm{Ma}$ than immediately before and after. Although high misfit values $(\mu \geq 10)$ are obtained in Formazza for models with two exhumation pulses, they do not allow us to reject this hypothesis because, as detailed in the previous paragraph, the age distribution does not allow a good resolution on events older than $6 \mathrm{Ma}$.

[38] Finally, we tested two different intensities of singlestep change in exhumation rate occurring between 9 and $2 \mathrm{Ma}$, with faster exhumation lasting until present (Figure 14). The relief conditions were either constant, increased from $\beta=0.7$ since the exhumation rate increase or decreased from $\beta=1.3$ over the same period. Misfit values obtained in Guttannen for such scenarios are clearly larger than misfits obtained for other scenarios $(\mu \geq 9.7)$. In Formazza, however, a low misfit value $(\mu=4.8$, case $\mathrm{D}$ in Figures 14 and 15) is obtained for an increase in exhumation rate from 300 to $1000 \mathrm{~m} / \mathrm{Ma}$ at $\sim 5 \mathrm{Ma}$, with little effect of tested relief changes.

\section{Discussion}

[39] The qualitative interpretation of age-elevation relationships led us to propose that the late Neogene denudation history of the central Alps is characterized by two distinct episodes of high exhumation rate, the first between 9 and $7 \mathrm{Ma}$ recorded in the Aar Massif, and the second between 5 and $3 \mathrm{Ma}$ recorded in the Lepontine Alps. A recent study in the Mont Blanc Massif [Glotzbach et al., 2008] described two periods of rapid exhumation, before $6 \mathrm{Ma}$ and after $3 \mathrm{Ma}$, thus proposing a three-phase scenario comparable to the qualitative interpretation of our elevation profiles (although with a slightly different timing).

[40] The numerical modeling scenario leading to the lowest misfit value in Guttannen (case C in Figures 13 and 15) supports the qualitative interpretation of elevation profiles detailed above. However, the fact that a steady exhumation scenario with valley deepening (case $\mathrm{A}$ in
Figures 11 and 15) leads to practically the same misfit suggests that either the ages in the Guttanen area do not resolve these pulses of exhumation with sufficient resolution, or that such pulses do not exist. In Formazza, the same conclusion is reached with two scenarios of either steady exhumation rate (case B in Figures 11 and 15), or exhumation rate increase since $\sim 5 \mathrm{Ma}$ (case D in Figures 14 and 15) yielding similar misfit values. The former scenario is in agreement with detrital FT data that have been argued to show exhumational steady state in the Lepontine area since at least $20 \mathrm{Ma}$ at rates of $\sim 700 \mathrm{~m} / \mathrm{Ma}$ [Bernet et al., 2001; Garzanti and Malusà, 2008]. Taken together, the best fitting models in Guttannen and Formazza do not support a common two-phase exhumation history affecting the two study areas and more generally the Western Alps. Nevertheless, we are unable to delineate unambiguously the late Neogene exhumation history in these two areas, based on available AFT and AHe ages. A higher number of age data spanning a longer period (possibly including higher-temperature thermochronometers), combined with a more rigorous exploration of the parameter space using an inverse approach [e.g., Braun and Robert, 2005] would enable to determine the best fit scenarios with more accuracy.

[41] Our observations only give partial support to Cederbom et al.'s [2004] hypothesis of a major pulse of exhumation in the axial chain since $5 \mathrm{Ma}$, facilitated by a change to a more erosive climate. Our conclusions provide support, albeit ambiguous, for a temporal signal of increased exhumation since circa $5 \mathrm{Ma}$, which appears to be a widespread phenomenon in the Alps [Vernon et al., 2008]. However, Cederbom et al. [2004] predicted that $6500 \mathrm{~m}$ of exhumation of the chain axis was necessary to trigger the observed $>1400 \mathrm{~m}$ of flexural isostatic rock uplift and denudation in the foreland. In contrast, post-5 Ma exhumation in Guttannen and Formazza, as predicted by our four best fit models reached 2000 to $2300 \mathrm{~m}$ and 3750 to $5000 \mathrm{~m}$, respectively. The discrepancy with Cederbom et al.'s [2004] prediction, however, is possibly due to the their use of a simplified isostatic rebound calculation; further 2-D flexural isostatic modeling that integrates the change in the distributed load accounting for erosion in the axial zones and the foreland basin itself is required to fully assess the significance of these numbers.

\section{Conclusions}

[42] Our new thermochronology data from the central European Alps enables us to draw the following conclusions:

[43] 1. Alpha-ejection-corrected AHe ages are in many cases older than AFT ages in our study. This problem might be partly explained by our observation of internally zoned induced fission tracks on external detectors used for AFT dating. Higher concentrations of radiogenic elements in the core of apatite crystals would lead to an overcorrection of AHe ages by the $\mathrm{F}_{\mathrm{t}}$ correction factor.

[44] 2. A first approach of data analysis based on the qualitative interpretation of the two elevation profiles suggests a common suite of events for our two study areas, albeit involving different amounts of post-5 Ma exhumation. In 
both the Guttannen (Aar Massif) and the Formazza (Lepontine Dome) areas, two periods of rapid exhumation at 9$7 \mathrm{Ma}$ (documented in Guttannen) and 5-3 Ma (documented in Formazza) would be separated by a 7-5 Ma period of slow exhumation through the AFT partial annealing zone.

[45] 3. Numerical modeling predictions of AFT and AHe ages for several exhumation and relief change scenarios only give partial support to the above hypothesis in Guttannen, where one of the two best fitting scenarios involves an increase in exhumation rates from 300 to $700 \mathrm{~m} / \mathrm{Ma}$ at 9-7 Ma, followed by a second pulse at 5-3 Ma, during relief increase. However, another best fitting scenario in Guttannen involves a constant $400 \mathrm{~m} / \mathrm{Ma}$ exhumation rate with valley deepening. In Formazza, the models favor either exhumation at a constant rate of $750 \mathrm{~m} / \mathrm{Ma}$, or an exhumation rate increasing from 300 to $1000 \mathrm{~m} / \mathrm{Ma}$ at $\sim 5 \mathrm{Ma}$ and constant since then, with little effect of relief change. As a result, the exhumation histories in Guttannen and Formazza appear clearly different, in contradiction with the qualitative interpretation provided above. Our results underline the weakness of exhumation scenarios borne exclusively by the interpretation of the slope of age-elevation profiles. It also stresses the potential of methods enabling testing a higher number of randomly chosen sets of exhumation, thermal and flexural parameters.

[46] 4. AFT ages along a N-S profile stretching across the central Alps are significantly older in the Aar Massif than in the western Lepontine Dome area (circa 7 Ma versus $4 \mathrm{Ma}$ ). According to the difference in elevation of a $\sim 6$ Ma partial annealing zone between the two profiles, the excess of denudation in the southern part of the transect reaches more than $\sim 1550 \mathrm{~m}$.
[47] 5. A similar number of at least $1450 \mathrm{~m}$ of differential exhumation is obtained from the estimates of exhumation since $5 \mathrm{Ma}$ according to the four exhumation scenarios yielding the lowest misfit values in Pecube tests; 2000 to $2300 \mathrm{~m}$ in Guttannen and 3750 to $5000 \mathrm{~m}$ in Formazza. These values are significantly lower than the $6500 \mathrm{~m}$ of denudation over the axial chain, calculated by Cederbom et al. [2004] as required to explain the Pliocene exhumation of the Swiss Molasse basin by flexural isostatic rebound. The difference may arise from underestimation of the European plate elastic thickness in the flexural isostatic modeling performed by these authors, and/or a rather unsophisticated treatment of the modified load distributions.

[48] 6. The documentation of strong spatial variations in the amount of exhumation since $5 \mathrm{Ma}$ between different massifs of the northern Western Alps suggests a localization of controls on erosion during Pliocene times. These controls may arise from either localized tectonic activity driving rock uplift, variable changes in precipitation, or variations in the rock strength of the eroded column. Whichever possibility, erosion of the Alpine orogen since $5 \mathrm{Ma}$ has been spatially variable.

[49] Acknowledgments. Meinert Rahn contributed to sampling strategy. We thank Charlotte Cederbom and Jean-Daniel Champagnac for insightful discussions on alpine uplift and exhumation. Valérie Olive made the ICP-MS measurements, and Cécile Gautheron performed Monte Carlo modeling of He ejection presented in Figure 8. Reviewers Frédéric Herman and Sean Willett, as well as Associate Editor Todd Ehlers, provided thoughtful comments which significantly contributed to improve this manuscript. Erika Labrin, Bardhyl Muceku, and Francois Senebier provided invaluable help in preparing samples and teaching techniques to A.V. This study was supported by an INSU-CNRS "Reliefs de la Terre" program grant to P.v.d.B., a University of Edinburgh Ph.D. teaching studentship and an international student mobility (MIRA) grant of the Rhône-Alpes region to A.V.

\section{References}

Abrecht, J. (1994), Geologic units of the Aar massif and their pre-Alpine rock associations: A critical review, Schweiz. Mineral. Petrogr. Mitt., 74, 5-27.

Bernet, M., M. Zattin, J. I. Garver, M. T. Brandon, and J. A. Vance (2001), Steady-state exhumation of the European Alps, Geology, 29, 35-38, doi:10.1130/ 0091-7613(2001)029<0035:SSEOTE $>2.0$. CO;2.

Bousquet, R., B. Goffé, P. Henry, X. Le Pichon, and C. Chopin (1997), Kinematic, thermal and petrological model of the central Alps: Lepontine metamorphism in the upper crust and eclogitisation of the lower crust, Tectonophysics, 273, 105-127, doi:10.1016/S0040-1951(96)00290-9.

Boyce, J. W., and K. V. Hodges (2005), U and Th zoning in Cerro de Mercado (Durango, Mexico) fluorapatite: Insights regarding the impact of recoil redistribution of radiogenic ${ }^{4} \mathrm{He}$ on $(\mathrm{U}-\mathrm{Th}) / \mathrm{He}$ thermochronology, Chem. Geol., 219, 261-274, doi:10.1016/j.chemgeo.2005.02.007.

Brandon, M. T. (1992), Decomposition of fission-track grain-age distributions, Am. J. Sci., 292, 535-564.

Brandon, M. T. (1996), Probability density plot for fission-track grain-age samples, Radiat. Meas., 26, 663-676, doi:10.1016/S1350-4487(97)82880-6.

Braun, J. (2002), Quantifying the effect of recent relief changes on age-elevation relationships, Earth Planet. Sci. Lett., 200, 331-343, doi:10.1016/S0012-821X(02) 00638-6.

Braun, J. (2003), Pecube: A new finite-element code to solve the $3 \mathrm{D}$ heat transport equation including the effects of a time-varying, finite amplitude surface topography, Comput. Geosci., 29, 787-794, doi:10.1016/ S0098-3004(03)00052-9.

Braun, J., and X. Robert (2005), Constraints on the rate of post-orogenic erosional decay from low-temperature thermochronological data: Application to the Dabie Shan, China, Earth Surf. Process. Landf., 30, 1203 1225, doi:10.1002/esp.1271.

Burov, E., and M. Diament (1996), Isostasy, equivalent elastic thickness, and inelastic rheology of continents and oceans, Geology, 24, 419-422, doi:10.1130 0091-7613(1996)024<0419:IEETAI >2.3.CO;2.

Cederbom, C. E., H. D. Sinclair, F. Schlunegger, and M. K. Rahn (2004), Climate-induced rebound and exhumation of the European Alps, Geology, 32, 709-712, doi:10.1130/G20491.1.

Challandes, N. (2001), Comportement des systèmes isotopiques 39Ar-40Ar et $\mathrm{Rb}-\mathrm{Sr}$ dans les zones de cisaillement: Exemples du massif de l'Aar (massif cristallins externes) et de la nappe de Suretta (Alpes centrales suisses), Ph.D. thesis, 268 pp., Univ. de Neuchâtel, Neuchâtel, Switzerland.

Choukroune, P., and D. Gapais (1983), Strain pattern in the Aar Granite (Central Alps): Orthogneiss developed by bulk inhomogeneous flattening, J. Struct. Geol., 5 , 411-418, doi:10.1016/0191-8141(83)90027-5.

Davies, T. A., W. W. Hay, J. R. Southam, and T. R. Worseley (1977), Estimates of Cenozoic oceanic sedimentation rates, Science, 197, 53-55, doi:10.1126/ science.197.4298.53.

Dunai, T. J. (2005), Forward modeling and interpretation of (U-Th)/He ages, in Low-Temperature Thermo- chronology: Techniques, Interpretations, and Applications, Rev. Mineral. Geochem, vol. 58, edited by P. W. Reiners and T. A. Ehlers, pp. 259-274, Mineral. Soc. of Am., Chantilly, Va.

Dunkl, I. (2002), TRACKKEY: A Windows program for calculation and graphical presentation of fission track data, Comput. Geosci., 28, 3-12, doi:10.1016/ S0098-3004(01)00024-3.

Evans, N. J., J. P. Byrne, J. T. Keegan, and L. E. Dotter (2005), Determination of uranium and thorium in zircon, apatite, and fluorite: Application to laser (U-Th)/He thermochronology, J. Anal. Chem., 60, 1159-1165, doi:10.1007/s10809-005-0260-1.

Fantoni, R., R. Bersezio, and F. Forcella (2004), Alpine structure and deformation chronology at the Southern Alps-Po Plain border in Lombardy, Boll. Soc. Geol. Ital., 123, 463-476.

Farley, K. A. (2000), Helium diffusion from apatite: General behavior as illustrated by Durango fluorapatite, J. Geophys. Res., 105, 2903-2914, doi:10.1029/1999JB900348.

Farley, K. A. (2002), (U-Th)/He dating: Techniques, calibrations, and applications, in Noble Gases in Geochemistry and Cosmochemistry, Rev. Mineral. Geochem., vol. 47, edited by D. Porcelli, C. J. Ballentine, and R. Wieler, pp. 819-843, Mineral. Soc. of Am., Chantilly, Va.

Farley, K. A., R. A. Wolf, and L. T. Silver (1996), The effects of long alpha-stopping distances on (U-Th)/ He ages, Geochim. Cosmochim. Acta, 60, 42234229, doi:10.1016/S0016-7037(96)00193-7. 
Foeken, J. P. T., F. M. Stuart, K. J. Dobson, C. Persano, and D. Vilbert (2006), A diode laser system for heating minerals for (U-Th)/He chronometry, Geochem. Geophys. Geosyst., 7, Q04015, doi:10.1029/2005GC001190.

Frey, M., and R. Ferreiro Mählmann (1999), Alpine metamorphism of the Central Alps, Schweiz. Mineral. Petrogr. Mitt., 79, 135-154.

Garzanti, E., and M. G. Malusà (2008), The Oligocene Alps: Domal unroofing and drainage development during early orogenic growth, Earth Planet. Sci. Lett., 268, 487-500, doi:10.1016/j.epsl.2008.01.039.

Gautheron, C., L. Tassan-Got, J. Barbarand, and M. Pagel (2008), Alpha-damage annealing effects on apatite $(\mathrm{U}-\mathrm{Th}) / \mathrm{He}$ thermochronometry, paper presented at 11th International Conference on Thermochronometry, Union Coll., Anchorage, Alaska, 15-19 Sept.

Gleadow, A. J. W. (1981), Fission-track dating methods: What are the real alternatives?, Nucl. Tracks, 5, 3-14, doi:10.1016/0191-278X(81)90021-4.

Glotzbach, C., J. Reinecker, M. Danišík, M. Rahn, W. Frisch, and C. Spiegel (2008), Neogene exhumation history of the Mont Blanc massif, Western Alps, Tectonics, 27, TC4011, doi:10.1029/2008TC002257.

Green, P. F., I. R. Duddy, G. M. Laslett, K. A. Hegarty, A. J. W. Gleadow, and J. F. Lovering (1989), Therma annealing of fission tracks in apatite 4. Quantitative modelling techniques and extension to geological timescales, Chem. Geol., 79, 155-182.

Green, P. F., P. V. Crowhurst, I. R. Duddy, P. Japsen, and S. P. Holford (2006), Conflicting (U-Th)/He and fission track ages in apatite: Enhanced He retention, not anomalous annealing behaviour, Earth Planet. Sci. Lett., 250, 407-427, doi:10.1016/j.eps1.2006.08.022.

Hendriks, B. W. H., and T. F. Redfield (2005), Apatite fission track and (U-Th)/He data from Fennoscandia: An example of underestimation of fission track annealing in apatite, Earth Planet. Sci. Lett., 236, 443 -458, doi:10.1016/j.eps1.2005.05.027.

Herman, F., J. Braun, T. J. Senden, and W. J. Dunlap (2007), (U-Th)/He thermochronometry: Mapping 3D geometry using micro-X-ray tomography and solving the associated production-diffusion equation, Chem. Geol., 242, 126-136, doi:10.1016/ j.chemgeo.2007.03.009.

Homewood, P., P. A. Allen, and G. D. Williams (1986), Dynamics of the Molasse Basin of western Switzerland, in Foreland Basins, edited by P. A. Allen and P. Homewood, Spec. Publ. Int. Assoc. Sedimentol., 8, 199-217

Hourigan, J. K., P. W. Reiners, and M. T. Brandon (2005), U-Th zonation-dependent alpha-ejection in (U-Th) He chronometry, Geochim. Cosmochim. Acta, 69 3349-3365, doi:10.1016/j.gca.2005.01.024.

Hunziker, J. C., J. Desmons, and A. J. Hurford (1992), Thirty-two years of geochronological work in the central and western Alps: A review on seven maps, Mem. Geol. Lausanne, 13, 59 pp.

Hurford, A. J. (1986), Cooling and uplift patterns in the Lepontine Alps, South Central Switzerland and an age of vertical movement of the Insubric fault line, Contrib. Mineral. Petrol., 92,413-427, doi:10.1007/ BF00374424

Hurford, A. J., and P. F. Green (1983), The zeta age calibration of fission-track dating, Chem. Geol., 1, $285-317$.

Keller, L. M., M. Hess, B. Fügenschuh, and S. Schmid (2005), Structural and metamorphic evolution of the Camughera-Moncucco, Antrona and Monte Rosa units southwest of the Simplon line, Western Alps, Eclogae Geol. Helv., 98, 19-49, doi:10.1007/ s00015-005-1149-6.

Kohl, T. (1999), Transient thermal effects below complex topographies, Tectonophysics, 306, 311-324, doi:10.1016/S0040-1951(99)00063-3.

Kuhlemann, J. (2000), Post-collisional sediment budget of circum-Alpine basins (central Europe), Mem. Sci. Geol. Padova, 52, 1-91.
Lihou, J., A. Hurford, and A. Carter (1995), Preliminary fission-track ages on zircons and apatites from the Sardona unit, Glarus Alps, eastern Switzerland: Late Miocene-Pliocene exhumation rates, Schweiz. Mineral. Petrogr. Mitt., 75, 177-186.

Mancktelow, N. S., and B. Grasemann (1997), Timedependent effects of heat advection and topography on cooling histories during erosion, Tectonophysics, 270, 167-195, doi:10.1016/S0040-1951(96)00279-X

Marquer, D., and M. Burkhard (1992), Fluid circulation, progressive deformation and mass-transfer processes in the upper crust: The example of basement-cover relationships in the External Crystalline Massifs, Switzerland, J. Struct. Geol., 14, 1047-1057, doi:10.1016/0191-8141(92)90035-U.

Marquer, D., and D. Gapais (1985), Les massifs cristallins externes sur une transversale Guttannen-Va Bedretto (Alpes centrales): Structures et histoires cinématiques, C. R. Acad. Sci., Ser. II, 301, 543-546.

Meesters, A. G. C. A., and T. J. Dunai (2002a), Solving the production-diffusion equation for finite diffusion domains of various shapes. Part I. Implications for low-temperature (U-Th)/He thermochronology, Chem. Geol., 186, 333-344, doi:10.1016/S0009 2541(01)00422-3.

Meesters, A. G. C. A., and T. J. Dunai (2002b), Solving the production-diffusion equation for finite diffusion domains of various shapes. Part II. Application to cases with $\alpha$-ejection and nonhomogeneous distribution of the source, Chem Geol., 186, 347-363, doi:10.1016/S0009-2541(02)00073-6.

Meesters, A. G. C. A., and T. J. Dunai (2005), A noniterative solution of the (U-Th)/He age equation, Geochem. Geophys. Geosyst., 6, Q04002, doi:10.1029/2004GC000834

Michalski, I., and M. Soom (1990), The Alpine thermotectonic evolution of the Aar and Gotthard massifs, central Switzerland: Fission-track ages on zircon and apatites and K-Ar mica ages, Schweiz. Mineral. Petrogr. Mitt., 70, 373-387.

Molnar, P. (2004), Late Cenozoic increase in accumulation rates of terrestrial sediment: How might climate change have affected erosion rates?, Annu. Rev. Earth Planet. Sci, 32, 67-89, doi:10.1146/annurev. earth.32.091003.143456.

O'Sullivan, P. B., and R. R. Parrish (1995), The importance of apatite composition and single grain age when interpreting fission track data from plutonic rocks: A case study from the Coast Ranges, British Columbia, Earth Planet. Sci. Lett., 132, 213-224, doi:10.1016/0012-821X(95)00058-K

Rahn, M. K., and B. Grasemann (1999), Fission track and numerical thermal modeling of differential exhumation of the Glarus thrust plane (Switzerland), Earth Planet. Sci. Lett., 169, 245-259, doi:10.1016/S0012 821X(99)00078-3.

Rahn, M. K., A. J. Hurford, and M. Frey (1997), Rotation and exhumation of a thrust plane: Apatite fission-track data from the Glarus thrust, Switzerland, Geology, 25, 599-602, doi:10.1130/0091-7613(1997)025<0599: RAEOAT $>2.3 . \mathrm{CO} ; 2$

Reiners, P. W., T. A. Ehlers, and P. K. Zeitler (2005), Past, present, and future of thermochronology, in Low-Temperature Thermochronology: Techniques, Interpretations, and Applications, Rev. Mineral. Geochem., vol. 58, edited by P. W. Reiners and T. A. Ehlers, pp. 1-18, Mineral. Soc. of Am. Chantilly, Va.

Scardia, G., G. Muttoni, and D. Sciunnach (2006), Subsurface magnetostratigraphy of Pleistocene sediments from the Po Plain (Italy): Constraints on rates of sedimentation and rock uplift, Geol. Soc. Am. Bull., 118, 1299-1312, doi:10.1130/B25869.1.

Schaer, J. P., G. M. Reimer, and G. A. Wagner (1975), Actual and ancient uplift rate in the Gotthard region, Swiss Alps: A comparison between precise levelling and fission-track apatite age, Tectonophysics, 29 293-300, doi:10.1016/0040-1951(75)90154-7.
Schmid, S. M., O. A. Pfiffner, N. Froitzheim, G. Schönborn, and E. Kissling (1996), Geophysical-geological transect and tectonic evolution of the Swiss-Italian Alps, Tectonics, 15, 1036-1064, doi:10.1029/96TC00433.

Schmid, S. M., B. Fügenschuh, E. Kissling, and R. Schuster (2004), Tectonic map and overall architecture of the Alpine orogen, Eclogae Geol. Helv. 97, 93-117, doi:10.1007/s00015-004-1113-x.

Shuster, D. L., R. M. Flowers, and K. A. Farley (2006), The influence of natural radiation damage on helium diffusion kinetics in apatite, Earth Planet. Sci. Lett., 249, 148 -161, doi:10.1016/j.eps1.2006.07.028.

Spencer, A. S., B. Kohn, A. Gleadow, M. Norman, D. Belton, and T. Carter (2004), The importance of residing in a good neighbourhood: Rechecking the rules of the game for apatite (U-Th)/He thermochronometry, paper presented at 10th International Conference on Fission Track Dating and Thermochronology, Amsterdam, Netherlands.

Stampfli, G. M., J. Mosar, D. Marquer, R. Marchant, T. Baudin, and G. Borel (1998), Subduction and obduction processes in the Swiss Alps, Tectonophysics, 296, 159-204, doi:10.1016/S0040-1951(98)00142-5.

Stephenson, J., K. Gallagher, and C. C. Holmes (2006), A Bayesian approach to calibrating apatite fission track annealing models for laboratory and geological timescales, Geochim. Cosmochim. Acta, 70 5183-5200, doi:10.1016/j.gca.2006.07.027.

Stüwe, K., L. White, and R. Brown (1994), The influence of eroding topography on steady-state isotherms. Application to fission track analysis, Earth Planet. Sci. Lett., 124, 63-74, doi:10.1016/0012-821X(94) 00068-9.

Vernon, A. J., P. A. van der Beek, H. D. Sinclair, and M. K. Rahn (2008), Increase in late Neogene denudation of the European Alps confirmed by analysis of a fission-track thermochronology database, Earth Planet. Sci. Lett., 270, 316-329, doi:10.1016/j.eps1. 2008.03.053.

von Raumer, J., J. Abrecht, F. Bussy, B. Lombardo, R. P. Menot, and U. Schaltegger (1999), The Palaeozoic metamorphic evolution of the Alpine External Massifs, Schweiz. Mineral. Petrogr. Mitt., $79,5-22$.

Wagner, G. A., and G. M. Reimer (1972), Fission track tectonics: The tectonic interpretation of fission track apatite ages, Earth Planet. Sci. Lett., 14, $263-268$, doi:10.1016/0012-821X(72)90018-0.

Willett, S. D., F. Schlunegger, and V. Picotti (2006), Messinian climate change and erosional destruction of the central European Alps, Geology, 34, 613 -616, doi: $10.1130 / \mathrm{G} 22280.1$

Williamson, J. H. (1968), Least squares fitting of a straight line, Can. J. Phys., 46, 1845-1847.

Zhang, P., P. Molnar, and W. R. Downes (2001), Increased sedimentation rates and grain sizes $2-4 \mathrm{Myr}$ ago due to the influence of climate change on erosion rates, Nature, 410, 891 -897, doi:10.1038/35073504.

J. Foeken and F. M. Stuart, Isotope Geosciences Unit, Scottish Universities Environmental Research Centre, De Boelelaan 1085-1087, East Kilbride G75 OQF, UK.

C. Persano, Department of Geographical and Earth Sciences, University of Glasgow, University Avenue, Glasgow G12 8QQ, UK.

H. D. Sinclair, School of Geosciences, University of Edinburgh, Geography Building, Drummond Street, Edinburgh EH9 3JW, UK

P. A. van der Beek, Laboratoire de Géodynamique des Chaînes Alpines, Université Joseph Fourier, BP 53 , F-38041 Grenoble CEDEX, France.

A. J. Vernon, Department of Geosciences, University of Arizona, 1040 E 4th Street, Tucson, AZ 85721 , USA. (ajvernon@email.arizona.edu) 